\title{
Disinfectant and Antimicrobial Susceptibility Studies of Staphylococcus aureus Strains and ST398-MRSA and ST5-MRSA Strains from Swine Mandibular Lymph Node Tissue, Commercial Pork Sausage Meat and Swine Feces
}

\author{
Ross C. Beier ${ }^{1, *(\mathbb{D})}$, Kathleen Andrews ${ }^{1}$, Michael E. Hume ${ }^{1} \mathbb{D}$, Muhammad Umar Sohail ${ }^{2} \mathbb{D}$, Roger B. Harvey $^{1} \mathbb{D}$, \\ Toni L. Poole ${ }^{1}(\mathbb{D})$, Tawni L. Crippen ${ }^{1}(\mathbb{D})$ and Robin C. Anderson ${ }^{1}(\mathbb{D}$ \\ 1 Food and Feed Safety Research Unit, Agricultural Research Service, Southern Plains Agricultural Research \\ Center, U.S. Department of Agriculture, 2881 F\&B Road, College Station, TX 77845, USA; \\ kate.andrews@usda.gov (K.A.); michael.hume@usda.gov (M.E.H.); roger.harvey@usda.gov (R.B.H.); \\ toni.poole@usda.gov (T.L.P.); tc.crippen@usda.gov (T.L.C.); robin.anderson@usda.gov (R.C.A.) \\ 2 Proteomics Core, Weill Cornell Medicine, Qatar Foundation-Education City, Doha P.O. Box 24144, Qatar; \\ mus4008@qatar-med.cornell.edu \\ * Correspondence: ross.beier@yahoo.com
}

Citation: Beier, R.C.; Andrews, K.; Hume, M.E.; Sohail, M.U.; Harvey, R.B.; Poole, T.L.; Crippen, T.L.; Anderson, R.C. Disinfectant and Antimicrobial Susceptibility Studies of Staphylococcus aureus Strains and ST398-MRSA and ST5-MRSA Strains from Swine Mandibular Lymph Node Tissue, Commercial Pork Sausage Meat and Swine Feces.

Microorganisms 2021, 9, 2401.

https://doi.org/10.3390/

microorganisms 9112401

Academic Editor: Edward Fox

Received: 4 November 2021

Accepted: 16 November 2021

Published: 22 November 2021

Publisher's Note: MDPI stays neutral with regard to jurisdictional claims in published maps and institutional affiliations.

Copyright: (c) 2021 by the authors. Licensee MDPI, Basel, Switzerland. This article is an open access article distributed under the terms and conditions of the Creative Commons Attribution (CC BY) license (https:/ / creativecommons.org/licenses/by/ $4.0 /)$.

\begin{abstract}
Staphylococcus aureus (S. aureus) causes gastrointestinal illness worldwide. Disinfectants are used throughout the food chain for pathogenic bacteria control. We investigated S. aureus bioavailability in swine Mandibular lymph node tissue (MLT) and pork sausage meat (PSM), established susceptibility values for $S$. aureus to disinfectants, and determined the multilocus sequence type of MRSA strains. Antimicrobial and disinfectant susceptibility profiles were determined for 164 S. aureus strains isolated from swine feces $(n=63)$, MLT $(n=49)$ and PSM $(n=52)$. No antimicrobial resistance (AMR) was detected to daptomycin, nitrofurantoin, linezolid, and tigecycline, while high AMR prevalence was determined to erythromycin (50.6\%), tylosin tartrate $(42.7 \%)$, penicillin $(72 \%)$, and tetracycline (68.9\%). Methicillin-resistant S. aureus (MRSA) strains, ST398 $(n=6)$ and ST5 $(n=1)$, were found in the MLT and PSM, 4 MRSA in MLT and 3 MRSA strains in the PSM. About $17.5 \%$ of feces strains and $41.6 \%$ of MLT and PSM strains were resistant to chlorhexidine. All strains were susceptible to triclosan and benzalkonium chloride, with no cross-resistance between antimicrobials and disinfectants. Six MRSA strains had elevated susceptibilities to 18 disinfectants. The use of formaldehyde and tris(hydroxylmethyl)nitromethane in DC\&R was not effective, which can add chemicals to the environment. Didecyldimethylammonium chloride and benzyldimethylhexadecylammonium chloride were equally effective disinfectants. ST398 and ST5 MRSA strains had elevated susceptibilities to $75 \%$ of the disinfectants tested. This study establishes susceptibility values for $S$. aureus strains from swine feces, mandibular lymph node tissue, and commercial pork sausage against 24 disinfectants. Since it was demonstrated that $S$. aureus and MRSA strains can be found deep within swine lymph node tissue, it may be beneficial for the consumer if raw swine lymph node tissue is not used in uncooked food products and pork sausage.
\end{abstract}

Keywords: antimicrobial; disinfectant; pork sausage meat; Staphylococcus aureus; swine; ST398; ST5; swine lymph node tissue

\section{Introduction}

Staphylococcus aureus (S. aureus) is a Gram-positive bacterial pathogen important worldwide because of its human health effects [1-5]. Toxic shock syndrome is often caused by toxins produced by $S$. aureus bacteria [6,7], and $S$. aureus is a well-known cause of hospital and community acquired diseases involving the bloodstream, endocarditis, lungs, meningitis, sepsis, skin, and soft tissue infections [8-14]. The Centers for Disease Control (CDC) has selected $S$. aureus as one of the top five pathogens causing foodborne illness in 
the United States [15]. Methicillin-resistant S. aureus (MRSA) was discovered soon after the first clinical application of the antibiotic methicillin [16]. Methicillin resistance in S. aureus results from the acquisition of the mecA gene, which codes for a penicillin binding protein (PBP2' or PBP2a) [4,17]. Therefore, MRSA is resistant to all penicillins [13] and commonly exhibits resistance to most $\beta$-lactams [18], such as amoxicillin and oxacillin, resulting in limited treatment options for MRSA infections [18,19]. An emerging S. aureus strain referred to as borderline oxacillin-resistant S. aureus (BORSA) does not have PBP2a and cannot be either classified as methicillin-resistant or methicillin-susceptible [20]. BORSA resistance results from hyperproduction of beta-lactamases or point mutations. Therefore, they may be misidentified causing a therapeutic threat. MRSA infections are a major problem, especially MRSA-associated bacteremia, which is a cause of endocarditis and sepsis resulting in morbidity and mortality [21].

S. aureus can cause foodborne illnesses if it enters the food-chain through contamination by food handlers or preparers [22,23], since people and other animals generally carry S. aureus in their nose and on their skin. S. aureus contamination may not affect the physical appearance of food, but toxins produced by S. aureus can cause food poisoning, leading to gastrointestinal illnesses [24]. Raw milk and raw milk cheese products have resulted in significant $S$. aureus food poisoning outbreaks worldwide [25-30]. Additionally, S. aureus is routinely found in raw or cooked meat, seafood, and vegetables $[26,27,29,31,32]$. Ground pork meat $[26,27]$ and sausage $[31,33]$ are commonly associated with gastroenteritis caused by MRSA [34], and staphylococcal food poisoning is an important foodborne disease worldwide [35], which is predominantly caused by S. aureus [36]. Beef [32] and pork sausage [32,37] are excellent media to promote the growth of $S$. aureus.

Pigs are routinely colonized by $S$. aureus strains [38] and can be considered a reservoir for S. aureus [3,4,39-41]. Pig- and other livestock-associated MRSA (LAMRSA) represents one of the largest MRSA reservoirs outside of the hospital setting [41]. LA-MRSA can be both a donor and recipient of antimicrobial resistance (AMR) genes [42]. The LA-MRSA clone most frequently detected is LA-MRSA clonal cluster 398 (CC398), which contains a wide array of resistance genes observed in numerous S. aureus strains [42]. The practice of exposing microorganisms to low levels of antimicrobials is common for growth promotion of food animals and can produce antimicrobial-resistant S. aureus [43,44], MRSA [25,45-48], and multidrug-resistant MRSA (MDRSA) [49,50]. CC398 strains have emerged in areas with a high-density of swine farms $[48,51-54]$ in the United States $[48,49,55]$ and Europe $[4,46,56-58]$. MRSA CC398 does not have host specificity and readily colonizes and causes infections in humans and other animals $[3,59]$. As a result, swine carriage of $S$. aureus can lead to occupational exposure to S. aureus [49,60-64] its multidrug-resistant MRSA (MDRSA) strains [54,65], and the potential for illness and hospitalization.

Prior to 1995 MRSA infections were predominantly associated with hospitalized patients (HA-MRSA) [54]. However, since the mid-1990s, MRSA has also been observed in community-associated infections (CA-MRSA) $[13,66]$. During the early 2000s a third type of MRSA from the community began emerging in humans [55] that belonged to CC398 [67]. CC398 is a group of at least five sequence types, each type characterized as sharing identical housekeeping genes [4]. This clonal cluster group is referred to as multilocus sequence type (MLST) 398 (ST398), since ST398 had the largest number of single-locus variants [68]. Thus, the threat imposed by CC398 emanates from the community, health care facilities, and is widely associated with food animal-producing farms.

Pathogenic bacteria that penetrate the food chain can cause foodborne illness. These bacteria can be derived from multiple locations, including from the farm, slaughterhouse, food processing centers, food handlers, and from handling food products within the home. These bacteria can be controlled through biocide (antiseptics and disinfectants) application programs $[69,70]$. A general definition of disinfectants was presented by White and McDermott [71], stating that disinfectants are chemicals that can kill or inhibit a broad-spectrum of microorganisms. However, if the levels of bio- 
cides used are lower than that required to kill the target bacteria, cross-resistance may be exacerbated $[69,72-82]$, and surviving bacteria may develop biofilms resulting in biocide tolerance and increased AMR [70,83-85]. The QAC didecyldimethylammonium chloride (DDAC) (referred to as C10AC in our laboratory to indicate the carbon chain length), was found to adsorb physicochemically onto the cell membrane where it could damage and disrupt the S. aureus membrane structure and function [86]. Further mode-of-action studies of C10AC and a mixture of $\mathrm{N}$-alkylbenzyldimethylammonium chlorides (BACs) against $S$. aureus showed that C10AC formed a double monolayer, and the BACs formed a single monolayer that covered the bacterial cells, resulting in substantial depletion of the potassium pool [87]. A study of the QAC benzalkonium chloride (BKC) against meat-associated Staphylococcus spp. demonstrated an open reading frame (ORF) on the plasmid pST827 that was similar to the QAC resistance genes $q a c C, e b r$, and $s m r$ [88]. Hydrogen peroxide and sodium hypochlorite [89,90] were more effective against $S$. aureus biofilms than quaternary ammonium chloride (QAC) disinfectants [91]. However, these studies were very limited in the number of S. aureus bacteria studied and the number of disinfectants tested [89-91]. Previously, our laboratory has also investigated the effects of a wide array of disinfectants on the inhibition of foodborne pathogens, Escherichia coli O157:H7 [92], Pseudomonas aeruginosa [93], non-O157 Shiga toxin-producing E. coli strains (STECs) [94], Salmonella spp. [95], Campylobacter coli [96], C. jejuni [70], and vancomycin-resistant enterococci (VRE) [97]. In all studies C10AC resulted in the best bacterial inhibition by an ammonium chloride except against $C$. coli, in which both C10AC and the BACs appeared to perform equally well, and synergistically in the complex disinfectant P-128 [96].

The current study evaluated the susceptibility of 164 S. aureus strains isolated from swine feces, swine mandibular lymph node tissue (MLT), and commercial pork sausage meat (PSM) against 16 antimicrobials, 17 disinfectants, and 7 disinfectant components. Multilocus sequence typing was conducted on the seven MRSA strains found in the MLT and PSM. The disinfectant component susceptibilities in some complex disinfectants were calculated and their individual potencies discussed. The potency of various individual disinfectant component ammonium chlorides with respect to the alkyl carbon chain length of the ammonium chlorides are discussed.

\section{Materials and Methods}

\subsection{Staphylococcus aureus Strains}

The 164 S. aureus strains were previously isolated from swine feces $(n=63)$, MLT $(n=49)$, and PSM $(n=52)$ [98]. The isolated bacteria were held at $-72{ }^{\circ} \mathrm{C}$ until used. Prior to experimentation, each $S$. aureus strain was grown for $24 \mathrm{~h}$ at $37^{\circ} \mathrm{C}$ on plates containing Trypticase $^{\mathrm{TM}}$ Soy Agar with 5\% sheep blood (TSA II ${ }^{\mathrm{TM}}$ ) (BD BBL ${ }^{\mathrm{TM}}$ Stacker ${ }^{\mathrm{TM}}$ Plate, Becton, Dickinson and Company, Sparks, MD, USA).

\subsection{Susceptibility Testing}

Antimicrobial susceptibility testing (AST) and disinfectant susceptibility testing (DST) were performed on the $164 \mathrm{~S}$. aureus strains using standard broth microdilution methods according to the Clinical and Laboratory Standards Institute $[99,100]$. Mueller-Hinton broth had previously been shown to not influence the results of suspension tests with disinfectants and E. coli DSM 682 or S. aureus ATCC 6538 [101]. The lowest concentration of the antimicrobial that had no visible $S$. aureus growth was determined to be the minimum inhibitory concentration (MIC) [102].

\subsection{Antimicrobial Susceptibility Testing}

AST was used to determine the S. aureus MICs against 16 antimicrobials using the National Antimicrobial Resistance Monitoring System (NARMS) Gram-positive plate (CMV3AGPF). The strains were adjusted to the proper concentration using a $0.5 \mathrm{McF}$ arland standard and dilution tubes containing demineralized water $(5 \mathrm{~mL})$ obtained from Remel 
Inc. (Lenexa, KS, USA). The inoculated demineralized water $(30 \mu \mathrm{L})$ was added to tubes containing $11 \mathrm{~mL}$ of cation-adjusted Mueller-Hinton broth (MHB) with TES (Tris, EDTA, and $\mathrm{NaCl}, \mathrm{pH} 8$ ) and dose heads (\#E3010) obtained from Remel Inc. were used to inoculate the antimicrobial-containing plates. MICs of the 164 S. aureus strains were obtained for 16 antimicrobials (Aminoglycosides: gentamicin (GEN), kanamycin, streptomycin (STR); Amphenicols: chloramphenicol (CHL); Cyclic lipopeptides: daptomycin; Fluoroquinolones: ciprofloxacin (CIP); Glycopeptides: vancomycin; Lincosamides: lincomycin; Macrolides: erythromycin (ERY), tylosin tartrate (TYLT); Nitrofurans: nitrofurantoin; Oxazolidinones: linezolid; Penicillins: penicillin (PEN); Streptogramins: quinupristin/dalfopristin (SYN); and Tetracyclines: tetracycline (TET), tigecycline) by following the manufacturer's instructions for the Sensititre ${ }^{\circledR}$ susceptibility system (Trek Diagnostic Systems Inc., Independence, OH, USA). Staphylococcus aureus ATCC 29213 and Pseudomonas aeruginosa ATCC 27853 were used as control strains for AST.

\subsection{DNA Isolation from MRSA Strains for Molecular Analysis}

MRSA strains were determined by traditional cefoxitin and oxacillin susceptibility tests of all isolated $S$. aureus strains followed by confirmation by polymerase chain reaction (PCR) methods [103]. A QIAmp ${ }^{\circledR}$ DNA Mini Kit (51306, Qiagen, Valencia, CA, USA) was used to isolate and purify genomic DNA from colonies of pure culture of $S$. aureus isolates. The colonies were grown on TSA II ${ }^{\mathrm{TM}}$ plates for $24 \mathrm{~h}$ at $37^{\circ} \mathrm{C}$. A loop-full $(10-\mu \mathrm{L}$ loop) of colonies were collected from the plate. Qiagen Protocol D under Protocols for Bacteria was followed for DNA isolation. For protocol D, $200 \mu \mathrm{g} / \mathrm{mL}$ of lysostaphin (L73861MG, Sigma-Aldrich, St. Louis, MO, USA) was used to pre-incubate the Gram-positive Staphylococcus cells. A NanoDrop ${ }^{\mathrm{TM}}$ One (13400518PR2, Thermo Fisher Scientific, Madison, WI, USA) spectrophotometer was used to obtain DNA concentrations and sample purity. Two-microliters of DNA-containing solution was used for each measurement.

\subsection{Multilocus Sequence Typing of the Extracted DNA}

Genomic DNA was sent to a commercial laboratory for Multilocus Sequence Typing (MLST) (Molecular Research Laboratory, Shallowater, TX, USA). S. aureus ATCC ${ }^{\circledR} 43300$ and S. aureus ATCC ${ }^{\circledR} 29213$ were used as controls for MLST testing. Molecular typing of the S. aureus isolates was performed by MLST software version 2.19.0 using Galaxy tools [104]. Alleles of each locus were compared, and sequence types were assigned based on the S. aureus MLST database [67].

\subsection{Disinfectant Susceptibility Testing}

In this work, 17 disinfectants and 7 disinfectant components, a total of 24 chemicals were evaluated by DST for inhibition of 164 S. aureus isolates [98] by methods similar to those previously described [97]. The sources and recommended uses for 21 of 24 chemicals tested were previously reported [95]. Briefly, a list of the 21 chemical disinfectants and disinfectant components with their abbreviations and with the added exponent " $\mathrm{CP}$ " to indicate a commercial product are listed as follows (name, abbreviation): benzalkonium chloride, BKC; Betadine ${ }^{\mathrm{CP}}$ (10\% povidone-iodine), P-I; cetylpyridinium bromide hydrate, CPB; DC\& $\mathrm{R}^{\mathrm{CP}}, \mathrm{DC} \& \mathrm{R}^{\mathrm{CP}}$; ethylhexadecyldimethylammonium bromide, CDEAB; Food Service Sanitizer $^{C P}$, FSS; F-25 Sanitizer ${ }^{C P}$, F25; Final Step 512 Sanitizer $^{C P}$, FS512; cetylpyridinium chloride hydrate, CPC; cetyltrimethylammonium bromide, CTAB; Novasan Solution ${ }^{\mathrm{CP}}$ (chlorhexidine diacetate), chlorhexidine; Odoban ${ }^{\mathrm{CP}}$, Odoban ${ }^{\mathrm{CP}}$; P-128 $8^{\mathrm{CP}}, \mathrm{P}-128^{\mathrm{CP}}$; Tek$\mathrm{Trol}^{\mathrm{CP}}$, Tek-Trol ${ }^{\mathrm{CP}}$; triclosan (ergasan), triclosan; didecyldimethylammonium chloride, C10AC; benzyldimethyldodecylammonium chloride, C12BAC; benzyldimethyltetradecylammonium chloride, C14BAC; benzyldimethylhexadecylammonium chloride, C16BAC; J.T. Baker 37\% formaldehyde, formaldehyde; and tris(hydroxylmethyl)nitromethane, THN. The additional three chemicals tested are the following: CaviCide ${ }^{C P}$ is a multi-purpose disinfectant that can be used on the hands as well as to decontaminate non-porous surfaces. CaviCide ${ }^{\mathrm{CP}}$ kills bacteria and viruses including but not limited to TB, Norovirus, 
HIV-1, HBV and HCV [105]. Triclocarban, or 3,4,4'-trichlorocarbanilide (TCC), is used worldwide as an antimicrobial both in personal care products (such as, bar soap, cleansing lotions, and deodorants) [106], and in pharmaceuticals [107]. Both CaviCide ${ }^{\mathrm{CP}}$ and TCC were obtained from Sigma-Aldrich (Milwaukee, WI, USA). TCC has been shown to be an endocrine disruptor $[108,109]$. The chemical, dioctyldimethylammonium chloride (C8AC), is a disinfectant component used in complex disinfectants and was obtained from Lonza Inc. (Fairlawn, NJ, USA). To aid the solubility of some chemicals, dimethyl sulfoxide (DMSO) (MilliporeSigma, St. Louis, MO, USA) was added to purified reverse-osmosis water $\left({ }^{\mathrm{RO}} \mathrm{H}_{2} \mathrm{O}\right)$ obtained using a water purification system from MilliporeSigma (Bedford, MA, USA).

Many disinfectants have multiple active components, and the percentages of active components in the complex disinfectants used in this study were previously provided [95]. The following disinfectants are mixtures of active components: F25, FS512, FSS, DC\&R ${ }^{C P}$, $\mathrm{P}-128^{\mathrm{CP}}$, and Tek-Trol ${ }^{\mathrm{CP}}$. S. aureus MICs for the disinfectants containing multiple active components have been determined using the authentic complex disinfectants. Triclosan resistance was determined by using the published susceptible/resistant criterion [110]; S. aureus bacteria were considered susceptible at MICs $<0.5 \mu \mathrm{g} / \mathrm{mL}$, were intermediate with MICs from 0.5 to $2 \mu \mathrm{g} / \mathrm{mL}$ and were considered resistant at MICs $>2 \mu \mathrm{g} / \mathrm{mL}$ triclosan. The breakpoint used for chlorhexidine against $S$. aureus was the same as previously used [111] for staphylococci bacteria; MICs $\geq 1 \mu \mathrm{g} / \mathrm{mL}$ were resistant. The susceptible/resistant criterion used for BKC was previously defined [112]; S. aureus at MICs $<30 \mu \mathrm{g} / \mathrm{mL}$ were considered susceptible, MICs from 30 to $50 \mu \mathrm{g} / \mathrm{mL}$ were assigned low-level resistance, and S. aureus at MICs $>50 \mu \mathrm{g} / \mathrm{mL}$ were considered resistant to BKC.

Dilutions of disinfectants and disinfectant components were made using ${ }^{\mathrm{RO}} \mathrm{H}_{2} \mathrm{O}$ followed by filter sterilization using $0.2 \mu \mathrm{m} \times 25 \mathrm{~mm}$ syringe filters (\#431224, Corning Inc., Corning, NY, USA). Some chemicals were not sufficiently soluble with pure ${ }^{R O} \mathrm{H}_{2} \mathrm{O}$ and required an addition of DMSO to achieve solubility. The chemicals that required added DMSO are listed using the following format: Chemical (\% DMSO added, \% DMSO in final solution). The chemicals requiring DMSO for solubility were the following: CPB (100\%, 5\%); CPC (30\%, 4.5\%); CTAB (100\%, 4.5\%); C14BAC (20\%, $1 \%)$; C16BAC (60\%, 1.5\%); TCC (80\%, 2.5\%); Tek-Trol ${ }^{\mathrm{CP}}(93 \%, 4 \%)$; THN (60\%, 2.5\%); and triclosan $(100 \%, 4 \%)$. The final working solutions of chemicals did not contain more than 5\% DMSO. The methods used to perform DST of S. aureus strains were similar to the DST conducted on Salmonella spp. [95] and Campylobacter coli [96]. The following concentration gradients were tested against the $164 \mathrm{~S}$. aureus strains. BKC, 0.25-256 $\mu \mathrm{g} / \mathrm{mL}$; CaviCide ${ }^{\mathrm{CP}}, 1-1024 \mu \mathrm{g} / \mathrm{mL}$; chlorhexidine, 0.008-8 $\mu \mathrm{g} / \mathrm{mL}$; CDEAB,

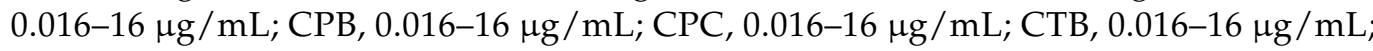

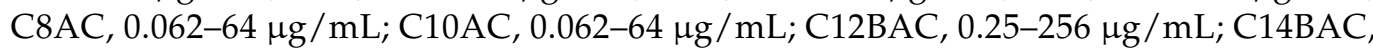
0.062-64 $\mu \mathrm{g} / \mathrm{mL}$; C16BAC, 0.062-64 $\mu \mathrm{g} / \mathrm{mL}$; DC\&R ${ }^{\mathrm{CP}}, 1-1024 \mu \mathrm{g} / \mathrm{mL}$; formaldehyde, 2-2048 $\mu \mathrm{g} / \mathrm{mL}$; FSS, 0.062-64 $\mu \mathrm{g} / \mathrm{mL} ;$ FS512, 0.062-64 $\mu \mathrm{g} / \mathrm{mL} ;$ F25, 0.062-64 $\mu \mathrm{g} / \mathrm{mL}$; OdoBan $^{\mathrm{CP}}$, 0.062-64 $\mu \mathrm{g} / \mathrm{mL}$; P-I, 32-32,768 $\mu \mathrm{g} / \mathrm{mL} ; \mathrm{P}-128^{\mathrm{CP}}, 0.016-16 \mu \mathrm{g} / \mathrm{mL}$; TekTrol $^{\mathrm{CP}}, 0.25-256 \mu \mathrm{g} / \mathrm{mL}$; triclosan, 0.002-2 $\mu \mathrm{g} / \mathrm{mL}$; THN, 2-2048 $\mu \mathrm{g} / \mathrm{mL}$; and TCC, 0.016-16 $\mu \mathrm{g} / \mathrm{mL}$. Staphylococcus aureus ATCC 29213 was used as the control strain for DST.

\subsection{Calculation of Theoretical MICs for Multiple Component Disinfectants}

The following calculations were used to obtain the theoretical MICs (theo MICs) for the active components in complex disinfectants. The theo MICs estimate the concentration levels of individual active ingredients in a disinfectant mixture.

2.7.1. Calculation of theo MICs for the Active Components of the Complex Disinfectant $\mathrm{DC} \& \mathrm{R}^{\mathrm{CP}}$ against $S$. aureus Strains

The active ingredients in DC\& $\mathrm{R}^{\mathrm{CP}}$ consists of a mixture of three disinfectant components, benzyl ammonium chlorides (BACs) (C12BAC-67\%, C14BAC-25\% and C16BAC-7\% 
and (C8BAC, C10BAC, and C18BAC)-1\%) at 3.08\%, formaldehyde (Form) at 2.28\%, and THN at $19.2 \%$. The theoretical MICs for each component in DC\&R ${ }^{C P}$, theo MIC ${ }_{B A C s}{ }^{D C \& R}$, ${ }^{\text {theo }} \mathrm{MIC}_{\mathrm{Form}}{ }^{\mathrm{DC} \& \mathrm{R}}$ and ${ }^{\text {theo }} \mathrm{MIC}_{\mathrm{THN}}{ }^{\mathrm{DC} \& \mathrm{R}}$, can be calculated by multiplying each determined DC\& $\mathrm{R}^{\mathrm{CP}}$ MIC by the percentage of each component $3.08,2.28$, and 19.2, respectively, and then dividing the result by the sum of the percentages for all active components in DC\& $\mathrm{R}^{\mathrm{CP}}$, which is 24.56, as previously described [95].

2.7.2. Calculation of theo MICs for the Active Components of the Complex Disinfectant $\mathrm{P}-128^{\mathrm{CP}}$ against $S$. aureus Strains

The active ingredients in $\mathrm{P}-128^{\mathrm{CP}}$ consists of a mixture of the BACs $(\mathrm{C} 12 \mathrm{BAC}-40 \%$, C14BAC-50\%, and C16BAC-10\%) at 3.38\% and C10AC at 5.07\%. The theo MICs for the active components of $\mathrm{P}-128^{\mathrm{CP}}$ can be calculated similarly to the DC\& $\mathrm{R}^{\mathrm{CP}}$ components above. Briefly, the theo MICs ${ }^{\mathrm{P}-128}$ of the two active components in $\mathrm{P}-128^{\mathrm{CP}}$, theo ${ }^{\mathrm{MIC}} \mathrm{s}_{\mathrm{BACs}}{ }^{\mathrm{P}-128}$ and ${ }^{\text {theo }} \mathrm{MICs}_{\mathrm{C} 10 \mathrm{AC}}{ }^{\mathrm{P}-128}$ can be obtained by multiplying each determined $\mathrm{P}-128^{\mathrm{CP}}$ MIC by the percentage of each component, 3.38 and 5.07, respectively, and then dividing by the sum of the component percentages in $\mathrm{P}-128^{\mathrm{CP}}$, which is 8.45 .

\section{Results}

\subsection{Antimicrobial Resistance}

Table 1 shows the AMR profiles among the 164 S. aureus strains isolated from swine feces, MLT, and PSM. Table 1 provides the $\mathrm{MIC}_{50}, \mathrm{MIC}_{90}, \mathrm{MIC}$ range of recorded values, the number of resistant strains and breakpoint used for each of the 16 antimicrobials tested against the $S$. aureus strains. No resistant strains were found against four different antimicrobials: daptomycin, nitrofurantoin, linezolid, and tigecycline. A low level of resistant strains was observed for the five antimicrobials: gentamicin $(0.6 \%)$, streptomycin $(2.4 \%)$, chloramphenicol (3.8\%), vancomycin (0.6\%), and quinupristin/dalfopristin (3.7\%). There were $21 / 164(12.8 \%)$ resistant $S$. aureus strains against ciprofloxacin. However, there was an observed high level of resistant strains against the four antimicrobials, erythromycin, tylosin tartrate, penicillin, and tetracycline at percentage levels of 50.6, 42.7, 72, and 68.9\%, respectively. When a bacterial strain exhibits a MIC [102] less than the breakpoint value for an antimicrobial it is considered susceptible to the antimicrobial. When the MIC is higher than the breakpoint it is considered resistant to the antimicrobial. The susceptible/resistant determination for $S$. aureus cannot be determined for kanamycin and lincomycin using the CMV3AGPF susceptibility plates since the lowest value for kanamycin on the susceptibility plate is $128 \mu \mathrm{g} / \mathrm{mL}$ but the kanamycin breakpoint is only $\geq 64 \mu \mathrm{g} / \mathrm{mL}$. The highest value of lincomycin on the susceptibility plate is $8 \mu \mathrm{g} / \mathrm{mL}$ and is far lower than the lincomycin breakpoint for $S$. aureus $(\geq 32 \mu \mathrm{g} / \mathrm{mL})$. The individual $S$. aureus AMR profiles for strains from swine feces is presented in Supplementary Table S1, the AMR profiles for the strains from the MLT are in Supplementary Table S2, and the AMR profiles for the strains isolated from the PSM are in Supplementary Table S3.

Resistance profiles for the 164 S. aureus strains are provided in Table 2 according to sample type, the number of multidrug-resistant (MDR) stains within each sample type, the number of antimicrobial-resistant strains, and the resistance profiles for each resistant strain. MDR strains are resistant to 3 or more classes of antimicrobials [113]. Out of 63 S. aureus strains isolated from swine feces, $32(50.8 \%)$ were shown to be MDR with the overall major resistance profile of ERY-TET-PEN-TYLT. There were 49 S. aureus strains isolated from the MLT, and 16 strains (32.7\%) were determined to be MDR with 4 (25.0\%) of these strains also determined to be MRSA [98]. There was no major resistance pattern in this group, except that MDR strains had seven unique resistance profiles. The two most prevalent resistance profiles found in the MLT MRSA strains were TET-PEN and TET-CIP-PEN. Out of 52 S. aureus strains, isolated from the PSM, only 15 strains (28.8\%) were MDR, including $3(20.0 \%)$ MRSAs [98]. Here too there was no single major resistance phenotype among the PSM MDR strains. However, there were 11 different resistance 
profiles among the PSM MDR strains, and the two resistance profiles found for the MRSA strains were TET-CIP-PEN and ERY-TET-CIP-PEN-TYLT.

Table 1. Antimicrobial resistance profiles among 164 Staphylococcus aureus strains isolated from swine feces, swine mandibular lymph node tissue, and commercial pork sausage meat. MIC = minimum inhibition concentration.

\begin{tabular}{|c|c|c|c|c|c|c|c|}
\hline Antimicrobial & $\begin{array}{c}\mathrm{MIC}_{50} \\
(\mu \mathrm{g} / \mathrm{mL})\end{array}$ & $\begin{array}{c}\mathrm{MIC}_{90} \\
(\mu \mathrm{g} / \mathrm{mL})\end{array}$ & \multicolumn{3}{|c|}{ MIC Range $(\mu \mathrm{g} / \mathrm{mL})$} & $\begin{array}{l}\text { No. (\%) } \\
\text { Resistant }\end{array}$ & $\begin{array}{c}\text { Breakpoint } \\
(\mu \mathrm{g} / \mathrm{mL})\end{array}$ \\
\hline \multicolumn{8}{|l|}{ Aminoglycosides } \\
\hline Gentamicin & $\leq 128$ & $\leq 128$ & \multicolumn{3}{|c|}{$\leq 128-1028$} & $1(0.6)$ & $>500$ \\
\hline Kanamycin & $\leq 128$ & $\leq 128$ & \multicolumn{3}{|c|}{$\leq 128$} & $\mathrm{CDR}^{*}$ & $\geq 64$ \\
\hline Streptomycin & $\leq 512$ & $\leq 512$ & \multicolumn{3}{|c|}{$\leq 512-2048$} & $4(2.4)$ & $\geq 1000$ \\
\hline \multicolumn{8}{|l|}{ Amphenicols } \\
\hline Chloramphenicol & 8 & 16 & \multicolumn{3}{|c|}{$8->32$} & $2(3.8)$ & $\geq 32$ \\
\hline \multicolumn{8}{|l|}{ Cyclic Lipopeptides } \\
\hline Daptomycin & $\leq 0.25$ & 0.5 & \multicolumn{3}{|c|}{$\leq 0.25-1$} & $0(0)$ & $>1$ \\
\hline \multicolumn{8}{|l|}{ Fluoroquinolones } \\
\hline Ciprofloxacin & 0.5 & $>4$ & \multicolumn{3}{|c|}{$0.12->4$} & $21(12.8)$ & $\geq 1$ \\
\hline \multicolumn{8}{|l|}{ Glycopeptides } \\
\hline Vancomycin & 0.5 & 1 & \multicolumn{3}{|c|}{$0.5-32$} & $1(0.6)$ & $\geq 16$ \\
\hline \multicolumn{8}{|l|}{ Lincosamides } \\
\hline Lincomycin & $>8$ & $>8$ & \multicolumn{3}{|c|}{$\leq 1->8$} & $\mathrm{CDR}^{*}$ & $\geq 32$ \\
\hline \multicolumn{8}{|l|}{ Macrolides } \\
\hline Erythromycin & $>8$ & $>8$ & \multicolumn{3}{|c|}{$\leq 0.25->8$} & $83(50.6)$ & $\geq 8$ \\
\hline Tylosin Tartrate & 2 & $>32$ & \multicolumn{3}{|c|}{$0.5->32$} & $70(42.7)$ & $\geq 20$ \\
\hline \multicolumn{8}{|l|}{ Nitrofurans } \\
\hline Nitrofurantoin & 16 & 16 & \multicolumn{3}{|c|}{$\leq 0.25-16$} & $0(0)$ & $\geq 128$ \\
\hline \multicolumn{8}{|l|}{ Oxazolidinones } \\
\hline Linezolid & 2 & 4 & \multicolumn{3}{|c|}{$\leq 0.5-4$} & $0(0)$ & $\geq 8$ \\
\hline \multicolumn{8}{|l|}{ Penicillins } \\
\hline Penicillin & $>16$ & $>16$ & \multicolumn{3}{|c|}{$\leq 0.25->16$} & $118(72)$ & $\geq 16$ \\
\hline \multicolumn{8}{|l|}{ Streptogramins } \\
\hline Quinupristin/Dalfopristin & $\leq 0.5$ & 1 & \multicolumn{3}{|c|}{$\leq 0.5-32$} & $6(3.7)$ & $\geq 4$ \\
\hline \multicolumn{8}{|l|}{ Tetracyclines } \\
\hline Tetracycline & $>32$ & $>32$ & \multicolumn{3}{|c|}{$\leq 1->32$} & $113(68.9)$ & $\geq 16$ \\
\hline \multirow[t]{2}{*}{ Tigecycline } & 0.25 & 0.5 & & $0.06-0.5$ & & $0(0)$ & $>0.5$ \\
\hline & & Number of & trains witl & Resistance to & the Numb & of Antibiot & \\
\hline No. of Antibiotics & 0 & 1 & 2 & 3 & 4 & 5 & 8 \\
\hline No. of Strains (\%) & $6(3.6)$ & 49 (29.9) & $28(17.1)$ & $28(17.1)$ & $39(23.8)$ & $13(7.9)$ & $1(0.6)$ \\
\hline
\end{tabular}


Table 2. Antimicrobial resistance and resistance profiles among 164 Staphylococcus aureus strains isolated from swine feces, swine mandibular lymph node tissue, and commercial pork sausage meat.

\begin{tabular}{|c|c|c|c|}
\hline Sample Type & $\begin{array}{l}\text { No. (\%) S. aureus } \\
\text { Strains Isolated }\end{array}$ & $\begin{array}{l}\text { No. Resistant } \\
\text { Strains }\end{array}$ & Resistance Profiles \\
\hline \multirow[t]{6}{*}{ Swine Feces } & 63 & 18 & PEN \\
\hline & & 3 & TET \\
\hline & & 7 & TET-PEN \\
\hline & & 3 & ERY-TET-TYLT \\
\hline & $\mathrm{MDR}=32(50.8 \%)$ & 31 & ERY-TET-PEN-TYLT \\
\hline & Strains & 1 & ERY-TET-CHL-PEN-TYLT \\
\hline \multirow[t]{10}{*}{ Lymph Node Tissue } & 49 & 10 & PEN \\
\hline & & 5 & TET \\
\hline & & 2 & ERY-TET \\
\hline & & 3 & ERY-PEN \\
\hline & & 1 & TET-CIP \\
\hline & & 1 & TET-PEN \\
\hline & & 10 & ERY-TET-TYLT \\
\hline & & 1 & ERY-PEN-TYLT \\
\hline & Strains: 147L, 150L & 2 & TET-PEN MRSA * \\
\hline & & 3 & ERY-TET-PEN \\
\hline $25.0 \%$ MDR Strains & Strains: $21 \mathrm{~L}, 38 \mathrm{~L}$ & 2 & TET-CIP-PEN MRSA * \\
\hline \multirow[t]{4}{*}{ were MRSA } & & 1 & ERY-TET-CIP-PEN \\
\hline & MDR = $16(32.7 \%)$ & 3 & ERY-TET-PEN-TYLT \\
\hline & Strains & 2 & ERY-TET-CIP-PEN-STR \\
\hline & & 3 & ERY-TET-CIP-PEN-TYLT \\
\hline \multirow[t]{11}{*}{ Pork Sausage Meat } & 52 & 6 & None \\
\hline & & 1 & CIP \\
\hline & & 5 & TET \\
\hline & & 7 & PEN \\
\hline & & 1 & ERY-TYLT \\
\hline & & 1 & TET-CHL \\
\hline & & 3 & TET-CIP \\
\hline & & 7 & TET-PEN \\
\hline & & 4 & ERY-PEN-TYLT \\
\hline & & 2 & ERY-TET-TYLT \\
\hline & & 1 & ERY-TET-PEN \\
\hline $20.0 \%$ MDR Strains & Strain: D16a & 1 & TET-CIP-PEN MRSA * \\
\hline \multirow[t]{6}{*}{ were MRSA } & & 1 & TET-CIP-PEN \\
\hline & MDR = $15(28.8 \%)$ & 1 & ERY-TET-PEN-TYLT \\
\hline & Strains & 1 & ERY-TET-TYLT-GEN \\
\hline & & 2 & ERY-TET-TYLT-SYN \\
\hline & Strains: D15, D16 & 2 & $\begin{array}{l}\text { ERY-TET-CIP-PEN-TYLT } \\
\text { MRSA * }\end{array}$ \\
\hline & & 2 & ERY-TET-CIP-PEN-TYLT \\
\hline
\end{tabular}


Table 2. Cont.

\begin{tabular}{cccl}
\hline Sample Type & $\begin{array}{c}\text { No. (\%) S. aureus } \\
\text { Strains Isolated }\end{array}$ & $\begin{array}{c}\text { No. Resistant } \\
\text { Strains }\end{array}$ & Resistance Profiles \\
\hline & 1 & ERY-TET-CIP-PEN-STR \\
\hline & 2 & ERY-TET-PEN-TYLT-SYN \\
\hline
\end{tabular}

${ }^{*}$ MRSA = methicillin-resistant $S$. aureus (resistant to cefoxitin and oxacillin) [98]; CHL, chloramphenicol; CIP, ciprofloxacin; ERY, erythromycin; GEN, gentamicin; PEN, penicillin; STR, streptomycin; SYN, quinupristin/dalfopristin; TET, tetracycline; TYLT, tylosin tartrate.

\subsection{Multilocus Sequence Typing}

The multilocus sequence typing data are presented in Table 3, which provides the sample number, bacteria type and MLST designation with the determined allelic profile.

Table 3. Molecular typing of MRSA (methicillin-resistant Staphylococcus aureus) strains isolated from swine mandibular lymph node tissue and commercial pork sausage meat.

\begin{tabular}{clc}
\hline Sample & \multicolumn{1}{c}{ Bacteria } & MLST Number (Allelic Profile) \\
\hline 21L & Wildtype S. aureus & $398(03-35-19-02-20-26-39)$ \\
38L & Wildtype S. aureus & $398(03-35-19-02-20-26-39)$ \\
147L & Wildtype S. aureus & $398(03-35-19-02-20-26-39)$ \\
150L & Wildtype S. aureus & $398(03-35-19-02-20-26-39)$ \\
D15 & Wildtype S. aureus & $5(01-04-01-04-12-01-10)$ \\
D16a & Wildtype S. aureus & $398(03-35-19-02-20-26-39)$ \\
D16 & Wildtype S. aureus & $398(03-35-19-02-20-26-39)$ \\
Control & S. aureus ATCC ${ }^{\circledR} 43300$ & $39(02-02-02-02-02-02-02)$ \\
Control & S. aureus ATCC ${ }^{\circledR} 29213$ & $5(01-04-01-04-12-01-10)$ \\
\hline
\end{tabular}

Six of the seven isolated MRSA strains from the MLT and PSM were determined to be strain ST398 and one strain was ST5.

\subsection{Disinfectant Susceptibility}

The MICs for the 63 S. aureus strains, isolated from swine feces determined against 24 disinfectants and disinfectant components, are shown in Table 4. The data for the swine feces set of strains are shown in a table by themselves because these strains differed in their interactions with disinfectants compared to strains isolated from the MLT and PSM, which are shown in Table 5. The S. aureus MICs for strains from the MLT and PSM were determined to be higher than the MICs for strains from swine feces against many of the disinfectants, such as DC\& $\mathrm{R}^{\mathrm{CP}}$, CaviCide ${ }^{\mathrm{CP}}, \mathrm{P}-128^{\mathrm{CP}}, \mathrm{P}-\mathrm{I}, \mathrm{FSS}, \mathrm{F} 25, \mathrm{FS} 512$, OdoBan ${ }^{\mathrm{CP}}, \mathrm{CPB}$, $\mathrm{CPC}, \mathrm{CDEAB}, \mathrm{CTAB}, \mathrm{C} 8 \mathrm{AC}, \mathrm{C} 10 \mathrm{AC}, \mathrm{C} 12 \mathrm{BAC}, \mathrm{C} 14 \mathrm{BAC}$, and THN. Swine feces strains were $17.5 \%$ resistant to chlorhexidine, whereas the group of strains from the MLT and PSM were determined to be $41.6 \%$ resistant to chlorhexidine. All strains studied showed no resistance to triclosan. Practically no difference in MICs between the two groups of strains was observed for BKC, C16BAC, formaldehyde, TCC, and Tek-Trol ${ }^{\mathrm{CP}}$. The elevated numbers highlighted in yellow in Table 5 show the MICs of six of the seven MRSA strains. The yellow highlighted numbers reflect that $75 \%$ of the disinfectants were determined to have increased S. aureus MICs in six of the seven MRSA strains. All MRSA strain MICs against the 24 disinfectants and disinfectant components tested are shown in Supplementary Table S4 with the elevated MICs highlighted in yellow. The disinfectant MICs for the 49 S. aureus strains isolated from the MLT are shown in Supplementary Table S5. The disinfectant MICs for the 52 S. aureus strains isolated from the PSM are shown in Supplementary Table S6. 
Table 4. Distribution of disinfectant susceptibility profiles for 63 Staphylococcus aureus strains isolated from swine feces. MIC = minimum inhibition concentration.

\begin{tabular}{|c|c|c|c|c|c|c|c|c|c|c|c|c|c|c|c|c|c|c|c|c|c|c|c|}
\hline \multirow[b]{2}{*}{ Disinfectant ${ }^{*}$} & \multicolumn{21}{|c|}{$\mathrm{MIC}(\mu \mathrm{g} / \mathrm{mL})$} & \multirow{2}{*}{$\begin{array}{l}\mathbf{M I C}_{50} \\
\mu \mathrm{g} / \mathrm{mL}\end{array}$} & \multirow{2}{*}{$\begin{array}{l}\mathbf{M I C}_{90} \\
\mathrm{~g} / \mathrm{mI}\end{array}$} \\
\hline & 0.008 & 0.0156 & 0.031 & 0.0625 & 0.125 & 0.25 & 0.5 & 1 & 2 & 4 & 8 & 16 & 32 & 64 & 128 & 256 & 512 & 1024 & 2048 & 4096 & 8192 & & \\
\hline $\mathrm{DC} \& \mathrm{R}^{\mathrm{CP}}$ & & & & & & & & & $6+$ & 29 & 28 & & & & & & & & & & & 4 & 8 \\
\hline Tek-Trol ${ }^{C P}$ & & & & & & & & & & & & & 15 & 48 & & & & & & & & 64 & 64 \\
\hline CaviCide $^{\mathrm{CP}}$ & & & & & & & & & & & & & & 25 & 38 & & & & & & & 128 & 128 \\
\hline Chlorhexidine $\ddagger$ & & & & & & & 52 & $10 \S$ & 1 & & & & & & & & & & & & & 0.5 & $1 \S$ \\
\hline Triclosan & & 1 & 15 & 26 & 17 & 3 & 1 & & & & & & & & & & & & & & & 0.062 & 0.125 \\
\hline TCC & & & & & 3 & 53 & 7 & & & & & & & & & & & & & & & 0.25 & 0.5 \\
\hline $\mathrm{P}-128^{\mathrm{CP}}$ & & & & & & 3 & 54 & 6 & & & & & & & & & & & & & & 0.5 & 0.5 \\
\hline $\mathrm{BKC}$ & & & & & & & 12 & 44 & 6 & 1 & & & & & & & & & & & & 1 & 2 \\
\hline P-I & & & & & & & & & & & & & & & & & 1 & 14 & 22 & 24 & 2 & 2048 & 4096 \\
\hline FSS & & & & & & 3 & 45 & 15 & & & & & & & & & & & & & & 0.5 & 1 \\
\hline F25 & & & & & & 1 & 43 & 18 & 1 & & & & & & & & & & & & & 0.5 & 1 \\
\hline FS512 & & & & & & 5 & 44 & 14 & & & & & & & & & & & & & & 0.5 & 1 \\
\hline OdoBan $^{\mathrm{CP}}$ & & & & & & & 32 & 31 & & & & & & & & & & & & & & 0.5 & 1 \\
\hline $\mathrm{CPB}$ & & & & & 3 & 29 & 27 & 4 & & & & & & & & & & & & & & 0.25 & 0.5 \\
\hline CDEAB & & & & & 1 & 7 & 34 & 21 & & & & & & & & & & & & & & 0.5 & 1 \\
\hline CTAB & & & & & & 1 & 30 & 28 & 4 & & & & & & & & & & & & & 1 & 1 \\
\hline C8AC II & & & & & & & & & 20 & 42 & 1 & & & & & & & & & & & 4 & 4 \\
\hline C10AC II & & & & & 2 & 19 & 41 & 1 & & & & & & & & & & & & & & 0.5 & 0.5 \\
\hline C12BAC II & & & & & & & 1 & 4 & 57 & 1 & & & & & & & & & & & & 2 & 2 \\
\hline C14BAC II & & & & & 1 & & 35 & 26 & & 1 & & & & & & & & & & & & 0.5 & 1 \\
\hline C16BAC II & & & & & & 7 & 34 & 16 & 6 & & & & & & & & & & & & & 0.5 & 1 \\
\hline THN II & & & & & & & & & & & & & & & 1 & 60 & 2 & & & & & 256 & 256 \\
\hline Formaldehyde II & & & & & & & & & & & & 1 & 18 & 43 & 1 & & & & & & & 64 & 64 \\
\hline
\end{tabular}

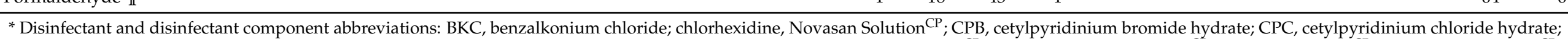

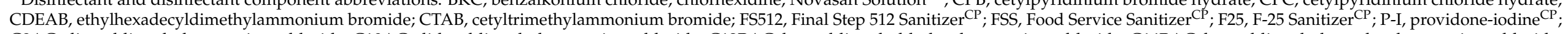

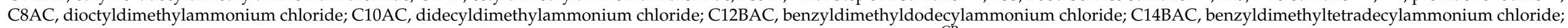

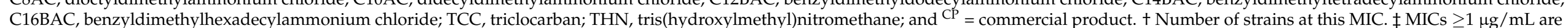
considered resistant to chlorhexidine [111]. § The entries in red indicate resistance. II This entry is a disinfectant component. 


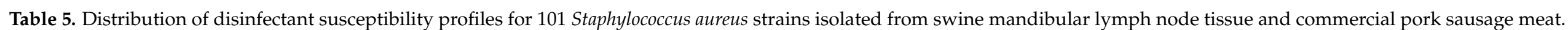
MIC = minimum inhibition concentration .

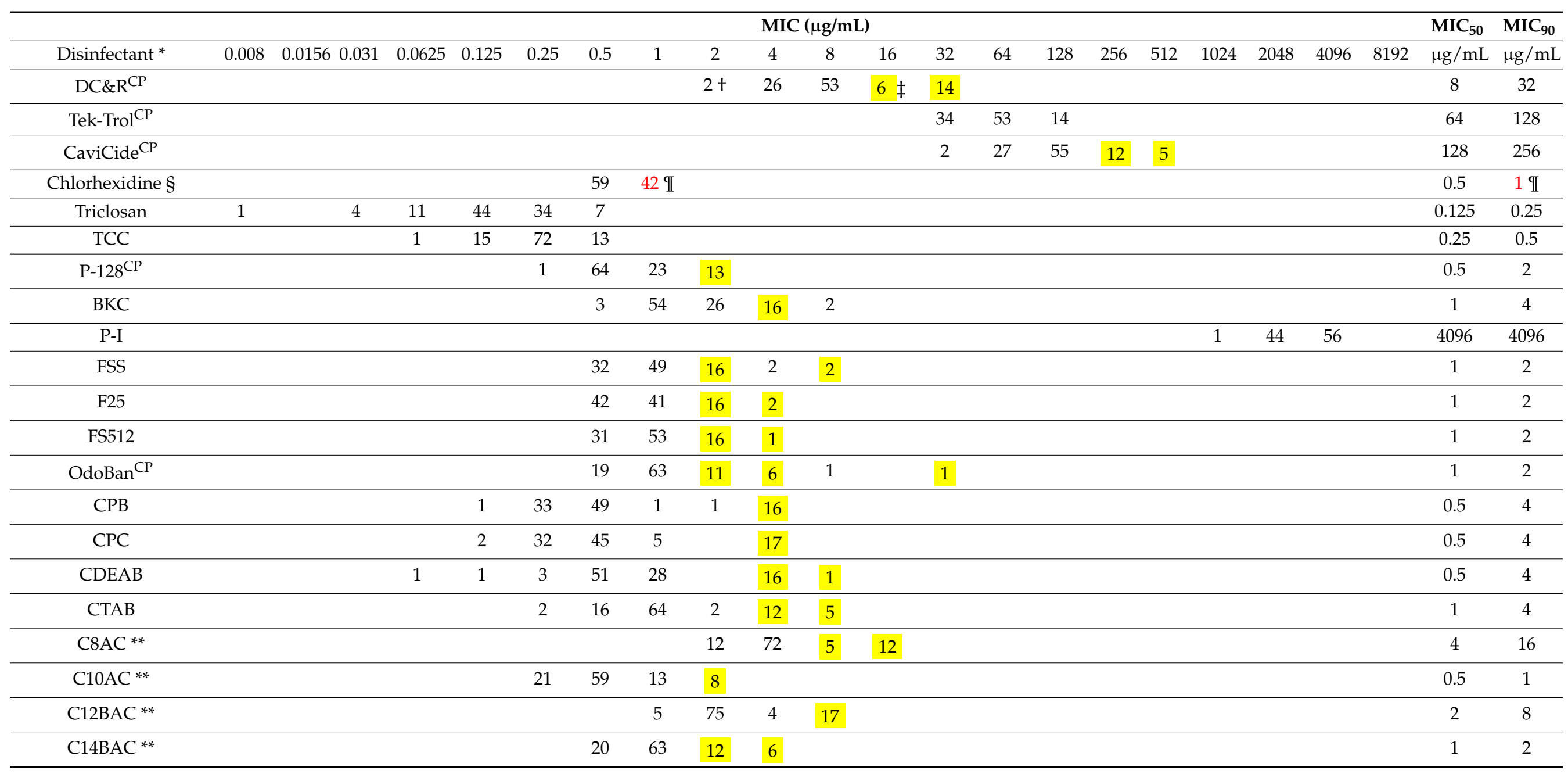


Table 5. Cont.

\section{$\operatorname{MIC}(\mu \mathrm{g} / \mathrm{mL})$}

$\mathrm{THN}^{* *}$

Formaldehyde **

2 2

78

20

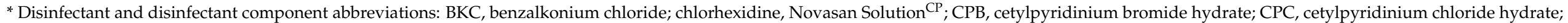

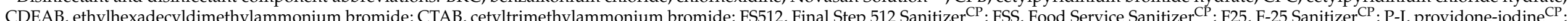

作

作

C16BAC, benzyldimethylhexadecylammonium chloride; TCC, triclocarban; THN, tris

in yellow show the MICs of 6 of 7 MRSA strains. $§$ MICs $\geq 1 \mu \mathrm{g} / \mathrm{mL}$ are considered resistant to chlorhexidine [111]. II The entries in red indicate resistance. ** This entry is a disinfectant component. 
Table 6 shows the correlation between $S$. aureus strains having increased disinfectant susceptibility with $S$. aureus MDR and MRSA strains. There were no strains from swine feces with elevated susceptibility to disinfectants. However, six $(12.3 \%)$ of the strains from the MLT and five $(9.6 \%)$ of the strains from the PSM had increased disinfectant susceptibility levels. There were four MRSA strains among the MLT strains and 3 MRSA strains among the PSM strains. One of the four MRSA strains from the MLT did not have elevated disinfectant susceptibility levels. Therefore, six of the seven MRSA strains had elevated disinfectant susceptibilities. All three MRSA strains isolated from PSM had elevated disinfectant susceptibility levels.

Table 6. Correlation between MDR and MRSA strains and strains showing elevated disinfectant susceptibility isolated from swine feces, swine mandibular lymph node tissue, and commercial pork sausage meat. $\mathrm{MDR}=$ multidrug-resistant, $\mathrm{MRSA}=$ methicillin-resistant Staphylococcus aureus.

\begin{tabular}{|c|c|c|c|}
\hline Sample Type & $\begin{array}{l}\text { No. of MDR * } \\
\text { S. aureus Strains }\end{array}$ & $\begin{array}{l}\text { No. of MRSA } \\
\text { Strains }+\end{array}$ & $\begin{array}{l}\text { No. of Strains with } \\
\text { Elevated Disinfectant } \\
\text { Susceptibility } \ddagger\end{array}$ \\
\hline Swine Feces & None & None & None \\
\hline \multirow{7}{*}{ Lymph Node Tissue } & + & + & - \\
\hline & + & + & $+\S, \mathbb{I}$ \\
\hline & + & + & $+\S, * *$ \\
\hline & + & + & $+\S, \mathbb{I}, * *$ \\
\hline & + & $-\S \S$ & $+\S$ \\
\hline & + & - & $+\stackrel{\mathscr{I}}{1}$ \\
\hline & 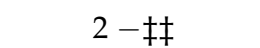 & - & $2+\S$ \\
\hline Semi-totals & $6(12.3 \%)$ & 4 strains & 7 strains \\
\hline \multirow[t]{6}{*}{ Pork Sausage Meat } & + & + & $+\S$ \\
\hline & + & + & $+t+$ \\
\hline & + & + & $+\S, * *,+\dagger$ \\
\hline & $2+$ & $-\S \S$ & $2+$ \\
\hline & $4-$ & - & $4+$ \\
\hline & - & - & $+\S, \mathbb{I}, * *$ \\
\hline Semi-totals & $5(9.6 \%)$ & 3 strains & 10 strains \\
\hline Totals & 11 strains & 7 strains & 17 strains \\
\hline \multicolumn{4}{|c|}{ 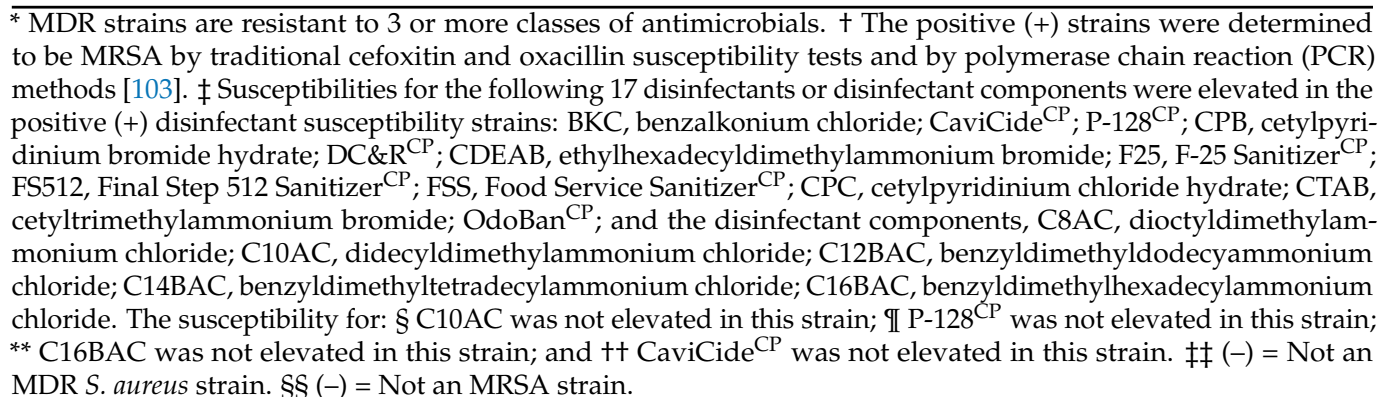 } \\
\hline
\end{tabular}

\subsection{Calculation of Theoretical MICs for Multiple Component Disinfectants}

Table 7 lists the calculated ${ }^{\text {theo }} \mathrm{MIC}$ s for the components of DC\&R $\mathrm{RP}^{\mathrm{CP}}$ and $\mathrm{P}-128^{\mathrm{CP}}$ against the feces, MLT and PSM strains in comparison to actual MICs for the same components against S. aureus. The calculated theo MICs for the BACs, formaldehyde and THN active components of

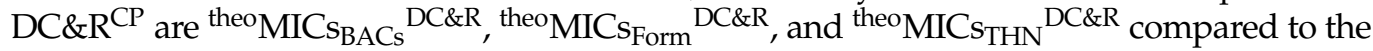
actual S. aureus MICs for swine feces strains against the BACs (C12BAC + C14BAC + C16BAC), formaldehyde, and THN (tris(hydroxylmethyl)nitromethane) found in Table 4. The calculated theo $\mathrm{MIC}_{\mathrm{BACs}}{ }^{\mathrm{DC} \& \mathrm{R}}$, theo MIC ${ }^{\mathrm{F}}$ orm ${ }^{\mathrm{DC} \& \mathrm{R}}$, and theo MIC ${ }_{\mathrm{THN}} \mathrm{DC} \& \mathrm{R}$ for the active components in DC\&R ${ }^{C P}$ compared to the actual S. aureus MICs for the MLT and PSM strains against the BACs, formaldehyde, and THN found in Table 5. The calculated theo MICs for the BACs and C10AC active components of $\mathrm{P}-128^{\mathrm{CP}}$ are ${ }^{\text {theo }} \mathrm{MICs}_{\mathrm{BACs}}{ }^{\mathrm{P}-128}$ and ${ }^{\text {theo }} \mathrm{MICs}_{\mathrm{C} 10 \mathrm{AC}}{ }^{\mathrm{P}-128}$ and are compared to the actual S. aureus MICs for these components, which are found in Table 4 for the BACs and for C10AC against swine feces strains. The calculated ${ }^{\text {theo }} \mathrm{MICs}_{\mathrm{BACs}}{ }^{\mathrm{P}-128}$ and 
theo MICs ${ }_{\mathrm{C} 10 \mathrm{AC}}^{\mathrm{P}-128}$ active components of $\mathrm{P}-128^{\mathrm{CP}}$ are compared to the actual S. aureus MICs, which are found in Table 5 for the BACs and for C10AC against the MLT and PSM strains. The

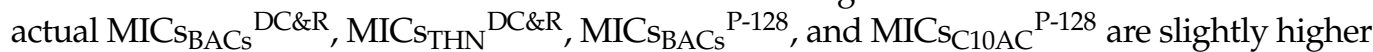
for the MLT and PSM strains than for the swine feces strains, while the MICs ${ }_{\text {Form }}{ }^{D C \& R}$ are generally unchanged. For the disinfectant $\mathrm{DC} \& \mathrm{R}^{\mathrm{CP}}$ the calculated ${ }^{\text {theo }}{ }^{\mathrm{MIC}} \mathrm{s}_{\mathrm{BACs}}{ }^{\mathrm{DC} \& \mathrm{R}}$ from the feces strains or from the MLT and PSM strains are in general relatively similar to the actual MICs necessary for S. aureus inhibition by the BACs seen in Tables 4 and 5 . The calculated ${ }^{\text {theo }} \mathrm{MICS}_{\mathrm{Form}}{ }^{\mathrm{DC} \& \mathrm{R}}$ and theo MICs ${ }_{\mathrm{THN}}{ }^{\mathrm{DC} \& \mathrm{R}}$ MICs for the swine feces strains or MLT and PSM strains are not similar to the actual MICs for formaldehyde and THN necessary for inhibition of $S$. aureus. For the disinfectant $\mathrm{P}-128^{\mathrm{CP}}$, the calculated ${ }^{\text {theo }}{ }^{\mathrm{MIC}} \mathrm{s}_{\mathrm{BACS}}{ }^{\mathrm{P}-128}$ from the feces strains, MLT and PSM strains are not high enough to inhibit most of the $S$. aureus strains tested (Table 7). However, the calculated ${ }^{\text {theo }} \mathrm{MICs}_{\mathrm{C} 10 \mathrm{AC}}{ }^{\mathrm{P}-128}$ are similar to the levels of $\mathrm{C} 10 \mathrm{AC}$ necessary for inhibition of $S$. aureus.

Table 7. Comparison of the calculated theoretical MICs ( $\left.{ }^{\text {theo }} \mathrm{MICs}\right)$ for components of DC\&R ${ }^{\mathrm{CP}}$ and $\mathrm{P}-128^{\mathrm{CP}}$ to the actual MIC levels of components required for inhibition of 63 Staphylococcus aureus strains isolated from feces to $101 \mathrm{~S}$. aureus strains from swine mandibular lymph node tissue and commercial pork sausage meat in $\mu \mathrm{g} / \mathrm{mL}$. MIC = minimum inhibition concentration.

\begin{tabular}{|c|c|c|c|c|c|}
\hline \multicolumn{3}{|c|}{ DC\&R Component MICs-Feces Strains } & \multicolumn{3}{|c|}{ DC\&R Component MICs-Tissue \& Sausage } \\
\hline Component & $\begin{array}{l}\text { Calculated } \\
\text { theo MICs }\end{array}$ & $\begin{array}{l}\text { Actual MICs } \\
\text { from Table } 3 *\end{array}$ & Component & $\begin{array}{l}\text { Calculated } \\
\text { theo MICs }\end{array}$ & $\begin{array}{l}\text { Actual MICs } \\
\text { from Table } 4+\end{array}$ \\
\hline \multirow[t]{6}{*}{ theo BACs ${ }^{\mathrm{DC} \& \mathrm{R}}$} & $0.25(9.6 \%) \ddagger$ & $0.125(0.5 \%) \ddagger$ & theo $\mathrm{BACs} \mathrm{s}^{\mathrm{DC} \& \mathrm{R}}$ & $0.25(2.0 \%) \ddagger$ & $0.25(1.0 \%) \ddagger$ \\
\hline & $0.5(46.0 \%)$ & $0.25(3.7 \%)$ & & $0.5(25.7 \%)$ & $0.5(31.0 \%)$ \\
\hline & $1.0(44.4 \%)$ & $0.5(37.0 \%)$ & & $1.0(52.5 \%)$ & $1.0(25.8 \%)$ \\
\hline & & $1.0(24.3 \%)$ & & $2.0(5.9 \%)$ & $2.0(33.3)$ \\
\hline & & $2.0(33.3 \%)$ & & $4.0(13.9 \%)$ & $4.0(3.3 \%)$ \\
\hline & & $4.0(1.1 \%)$ & & & $8.0(5.6 \%)$ \\
\hline \multirow[t]{5}{*}{${ }^{2}{ }^{\text {Form }}{ }^{\mathrm{DC} \& \mathrm{R}}$} & $0.19(9.5 \%) \ddagger$ & $16.0(1.6 \%) \ddagger$ & ${ }^{\text {theo }}$ Form $^{\text {DC\&R }}$ & $0.19(2.0 \%) \ddagger$ & $32.0(2.0 \%) \ddagger$ \\
\hline & $0.37(46.0 \%)$ & $32.0(28.6 \%)$ & & $0.37(25.7 \%)$ & $64.0(98.0 \%)$ \\
\hline & $0.74(44.4 \%)$ & $64.0(68.2 \%)$ & & $0.74(52.5 \%)$ & \\
\hline & & $128.0(1.6 \%)$ & & $1.49(5.9 \%)$ & \\
\hline & & & & $2.97(13.9 \%)$ & \\
\hline \multirow[t]{5}{*}{ theo $\mathrm{THN}^{\mathrm{DC} \& \mathrm{R}}$} & $1.56(9.5 \%) \ddagger$ & $128.0(1.6 \%) \ddagger$ & theo $\mathrm{THN}^{\mathrm{DC} \& \mathrm{R}}$ & $1.56(2.0 \%) \ddagger$ & $128.0(2.0 \%) \ddagger$ \\
\hline & $3.13(46.0 \%)$ & $256.0(95.2 \%)$ & & $3.13(25.7 \%)$ & $256.0(77.2 \%)$ \\
\hline & $6.25(44.4 \%)$ & $512.0(3.2 \%)$ & & $6.25(52.5 \%)$ & $512.0(19.8 \%)$ \\
\hline & & & & $12.51(5.9 \%)$ & $1024.0(1.0 \%)$ \\
\hline & & & & $25.0(13.9 \%)$ & \\
\hline \multicolumn{3}{|c|}{ P-128 Component MICs-Feces Strains } & \multicolumn{3}{|c|}{$\begin{array}{l}\text { P-128 Component MICs-Tissue \& Sausage } \\
\text { Strains }\end{array}$} \\
\hline \multirow[t]{6}{*}{${ }^{\text {theo }} \mathrm{BACs} \mathrm{s}^{\mathrm{P}-128}$} & $0.1(4.8 \%) \ddagger$ & $0.125(0.5 \%) \ddagger$ & theo ${ }^{\mathrm{BACs}}{ }^{\mathrm{P}-128}$ & $0.1(1.0 \%) \ddagger$ & $0.25(1.0 \%) \ddagger$ \\
\hline & $0.2(85.7 \%)$ & $0.25(3.7 \%)$ & & $0.2(63.4 \%)$ & $0.5(31.0 \%)$ \\
\hline & $0.4(9.5 \%)$ & $0.5(37.0 \%)$ & & $0.4(22.8 \%)$ & $1.0(25.7 \%)$ \\
\hline & & $1.0(24.3 \%)$ & & $0.8(12.9 \%)$ & $2.0(33.3 \%)$ \\
\hline & & $2.0(33.3 \%)$ & & & $4.0(3.3 \%)$ \\
\hline & & $4.0(1.1 \%)$ & & & $8.0(5.6 \%)$ \\
\hline \multirow[t]{4}{*}{ theo $\mathrm{C} 10 \mathrm{AC}^{\mathrm{P}-128}$} & $0.15(4.8 \%) \ddagger$ & $0.125(3.2 \%) \ddagger$ & theo $\mathrm{C} 10 \mathrm{AC} \mathrm{C}^{\mathrm{P}-128}$ & $0.15(1.0 \%) \ddagger$ & $0.25(20.8 \%) \ddagger$ \\
\hline & $0.3(85.7 \%)$ & $0.25(30.1 \%)$ & & $0.3(63.4 \%)$ & $0.5(58.4 \%)$ \\
\hline & $0.6(9.5 \%)$ & $0.5(65.1 \%)$ & & $0.6(22.8 \%)$ & $1.0(12.9 \%)$ \\
\hline & & $1.0(1.6 \%)$ & & $1.2(12.9 \%)$ & $2.0(7.9 \%)$ \\
\hline
\end{tabular}

* Component MICs obtained from Table 4 for the BACs, (C12BAC, C14BAC, and C16BAC), Form (formaldehyde), THN (tris(hydroxylmethyl)nitromethane), and C10AC (didecyldimethylammonium chloride) against $S$. aureus strains from feces. + Component MICs obtained from Table 5 for the BACs, (C12BAC, C14BAC, and C16BAC), formaldehyde, THN (tris(hydroxylmethyl)nitromethane), and C10AC (didecyldimethylammonium chloride) against $S$. aureus strains from the MLT and PSM. $\ddagger$ Percentage of strains at the indicated MIC. 


\subsection{Staphylococcus aureus Inhibition by Ammonium Chloride Disinfectant Components}

Figure 1 depicts the curves generated for the inhibition of $63 \mathrm{~S}$. aureus strains from swine feces by the ammonium chloride disinfectant components $\mathrm{C} 8 \mathrm{AC}, \mathrm{C} 10 \mathrm{AC}, \mathrm{C} 12 \mathrm{BAC}$, C14BAC, and C16BAC in $\mu \mathrm{mol} / \mathrm{L}(\mu \mathrm{M})$. Figure 2 shows the curves generated for the inhibition of 101 S. aureus strains from the MLT and PSM by the ammonium chloride disinfectant components C8AC, C10AC, C12BAC, C14BAC, and C16BAC in $\mu \mathrm{M}$. C10AC and $\mathrm{C} 16 \mathrm{BAC}$ were equally the most effective disinfectant components against $S$. aureus. While $\mathrm{C} 8 \mathrm{AC}, \mathrm{C} 10 \mathrm{AC}$, and $\mathrm{C} 12 \mathrm{BAC}$ required progressively higher levels to inhibit some of the MLT and PSM strains than for the swine feces S. aureus strains.

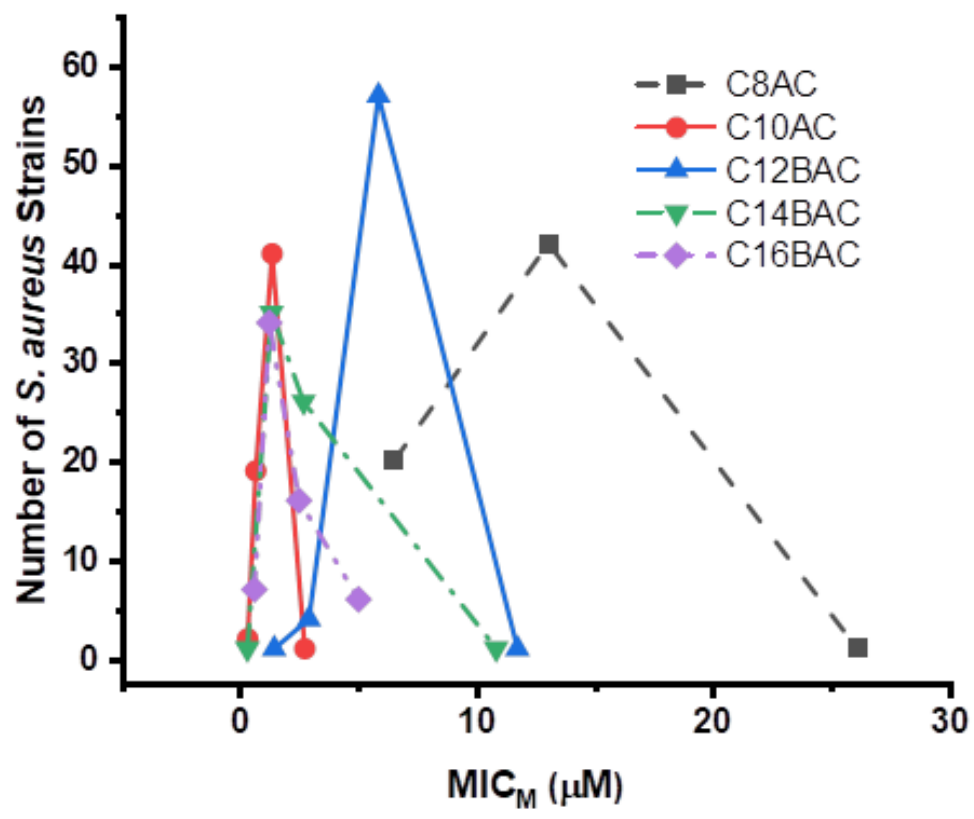

Figure 1. The number of Staphylococcus aureus strains at each molar $\mathrm{MIC}\left(\mathrm{MIC}_{\mathrm{M}}\right)$ for the 63 Staphylococcus aureus strains isolated from swine feces against five ammonium chloride disinfectant components.

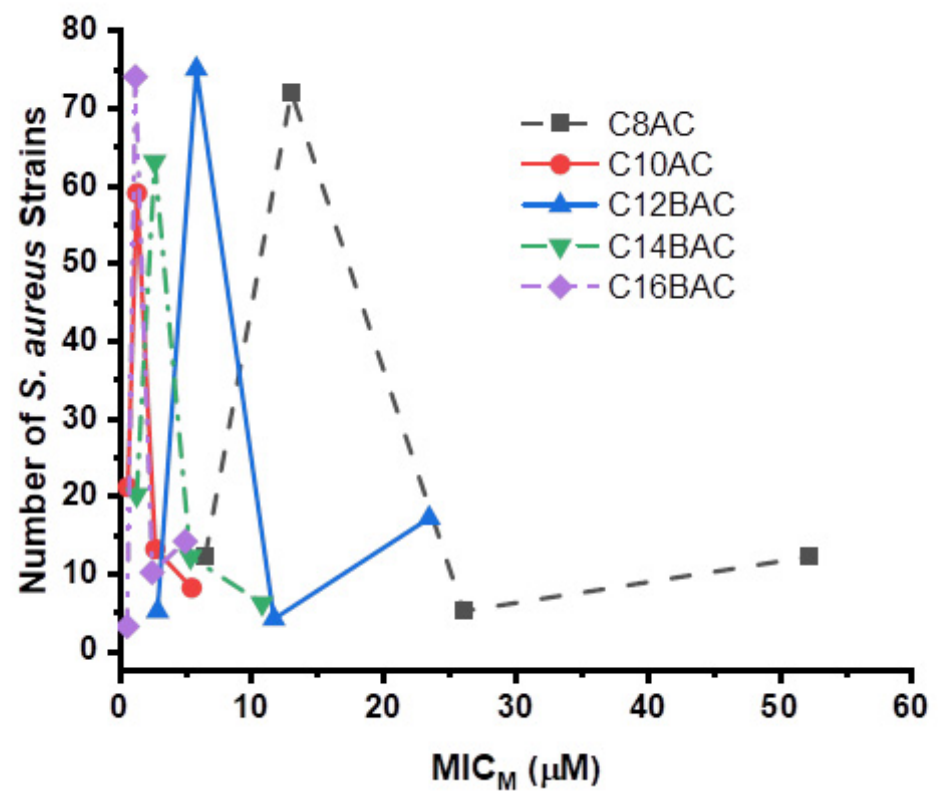

Figure 2. The number of Staphylococcus aureus strains at each molar MIC $\left(\mathrm{MIC}_{\mathrm{M}}\right)$ for the 101 Staphylococcus aureus strains isolated from swine mandibular lymph node tissue and commercial pork sausage meat against five ammonium chloride disinfectant components. 


\section{Discussion}

The 164 S. aureus strains isolated from swine feces, MLT, and PSM demonstrated no AMR to daptomycin, nitrofurantoin, linezolid, and tigecycline. These same strains showed very low AMR prevalence to gentamicin, streptomycin, chloramphenicol, vancomycin, and quinupristin/dalfopristin antimicrobials. Some strains showed AMR to ciprofloxacin; however, high AMR was demonstrated among the strains against erythromycin, tylosin tartrate (macrolides), penicillin, and tetracycline. A high level of S. aureus macrolide resistance has been observed and was suggested to be due to excessive use of the macrolide antibiotics [114]. As many as 60 resistance genes have been identified in S. aureus that can confer resistance to different classes of antimicrobials, such as $\beta$-lactam antibiotics, tetracyclines, and the macrolides [115]. The resistance profiles of the S. aureus strains studied here show swine feces strains had a limited number of resistance profiles compared to either the MLT or PSM strains. The MDR strains from both the MLT and PSM contained all the MRSA strains detected, and pork sausage has been shown to be an excellent growth medium for S. aureus [32,37]. Of the S. aureus strains isolated from the MLT, $32.7 \%$ were MDR and $25.0 \%$ of the MDR strains were MRSA. Of the S. aureus strains isolated from PSM, 28.8\% were MDR and 20.0\% of those were MRSA strains. Even though the number of MDR MLT strains were greater than the number of MDR PSM strains, the number of different resistance profiles were greater for the PSM MDR strains (13 profiles) than for the MLT MDR strains (nine profiles). Seven MRSA strains were isolated from the MLT and PSM, but no MRSA strains were observed among the strains isolated from swine feces. It was previously demonstrated that intracellular contamination of the MLT and PSM by MRSA was $8.2 \%$ and $5.8 \%$, respectively [98]; suggesting that the contamination levels of MRSA in swine tissues cannot be eliminated.

Multilocus sequence typing determined six of the seven MRSA strains isolated from the MLT and PSM belonged to strain ST398 while one belonged to strain ST5. A new clone of MRSA with the sequence type ST398 was first described in 2005 [45], and the first study showing a direct association between food animal and human carriage of ST398 was in 2010 [116]. The MRSA strain ST398 was demonstrated to be present in pigs [117-119] and in pig farmers [48,120]. MRSA strain ST398 was observed in humans and food animals in Central Europe [121], in humans in Northern Austria [122], Canada [123], the Dominican Republic and New York City [124], and in Midwestern U.S. swine and swine workers [48]. MRSA strain ST398 was observed in fresh pork meat in Germany [125] and in general can be found in final meat products if the pigs were colonized with ST398 [4]. Severe endocarditis, pneumonia, blood steam, and other infections can be caused by CA-MRSA ST398 [59,126-130]. Resistance gene analysis of LA-MRSA CC398 has demonstrated commonly found genes in S. aureus and other staphylococci but also novel resistance genes have been described [42]. It was observed at a hospital in South Korea that children were only infected at $6.8 \%$ with strain ST5, while adults were infected at a rate of $58 \%$ with strain ST5 [131].

Fifty-three of the 164 (32.3\%) S. aureus strains were resistant to chlorhexidine. Chlorhexidine resistance was observed in $17.5 \%$ of swine feces strains and $41.6 \%$ of the combined MLT and PSM strains, suggesting both swine MLT and PSM strains had a greater chance of becoming chlorhexidine resistant. In previous experiments, E. coli O157:H7 strains from cattle demonstrated only $11 \%$ resistance to chlorhexidine [92] and $32 \%$ of $C$. jejuni strains were resistant to chlorhexidine [70], but $76 \%$ of VRE strains were resistant to chlorhexidine [97]. While strains from non-O157 STECs [94], cattle Salmonella strains [95] and swine C. coli strains [96] were $\sim 90 \%$ resistant to chlorhexidine, and Ps. aeruginosa [93] and turkey Salmonella strains [132] were $100 \%$ resistant to chlorhexidine. All 164 S. aureus strains were susceptible to triclosan, which is similar as observed for Salmonella [95,132], E. coli O157:H7 [92], and the non-O157 STEC strains [94]. Our laboratory regularly refers to triclosan as a pseudo-antibiotic since it is synthetic and not a natural product but functions similarly as an antibiotic [96]. Triclosan is described in the literature as a biocide, but functions like an antimicrobial since it has a specific bacterial cellular target [133]. Tri- 
closan inhibits the final enzyme in the fatty-acid biosynthesis elongation cycle, the highly conserved enzyme enoyl-[acyl-carrier-protein] reductase (NADH) [110]. Triclosan is well known to affect efflux pumps and membrane permeability by causing genetic mutations in at least five genes in E. coli resulting in MDR [134], and Ps. aeruginosa [93], VRE [97], C. coli [96], and C. jejuni strains [70] are also highly resistant to triclosan.

All 164 S. aureus strains were susceptible to BKC. BKC is a biocide commonly used to preserve human ocular medications, and to clean animal wounds and prevent skin infections. BKC can be used for sanitization in the dairy industry, in fisheries, and on poultry farms [135], and can be used as a Covid-19 hand sanitizer [136]; however, any disinfectant that will disrupt a lipid bilayer will cause virus inactivation. In previous studies it was shown that $C$. jejuni [70], C. coli [96] and VRE [97] were susceptible to BKC. Some strains of E. coli O157:H7 [92], non-O157 STECs [94] and Salmonella from cattle [95], and most Salmonella strains from turkeys [132] have shown intermediate resistance to BKC, whereas $97.1 \%$ of 175 Ps. aeruginosa strains were resistant to BKC [93].

The 164 S. aureus swine strains had similar susceptibilities for the disinfectants TCC, P-I, THN, and formaldehyde. The MLT and PSM strains had elevated susceptibilities for DC\& ${ }^{\mathrm{CP}}$, Tek-Trol $^{\mathrm{CP}}$, CaviCide $^{\mathrm{CP}}, \mathrm{P}-128^{\mathrm{CP}}, \mathrm{BKC}, \mathrm{FSS}, \mathrm{F} 25, \mathrm{FS} 512$, OdoBan ${ }^{\mathrm{CP}}, \mathrm{CPB}, \mathrm{CPC}$, CDEAB, CTAB, C8AC, C10AC, C12BAC, C14BAC, and C16BAC compared to the swine feces strains. The MLT and PSM MRSA strains showed elevated susceptibilities to all these disinfectants and disinfectant components, except for Tek-Trol ${ }^{\mathrm{CP}}$ when compared to the swine feces strains. The MLT and PSM strains have similar disinfectant susceptibilities as was observed in C. jejuni [70], C. coli [96], and VRE strains [97]. The disinfectant susceptibilities for previously tested Salmonella [95,132], E. coli O157:H7 [92], and non-O157 STEC strains [94] were two- to four-fold higher than seen here for the MLT and PSM strains. Whereas the susceptibilities for previously tested Ps. aeruginosa strains [93] were 32- to 64-fold higher than obtained here for the MLT and PSM strains. The highest susceptibility values observed were for $S$. aureus against P-I. These levels are similar to those observed previously for $C$. jejuni and are in excess of 49- to 98 -fold less than the manufacturer suggested application rate of $100,000 \mu \mathrm{g} / \mathrm{mL}$ of a P-I solution directly applied to wound surfaces [70]. We were unable to observe cross-resistance between the antimicrobials tested and the disinfectants.

The number of MRSA strains correlated well with the strains that had increased disinfectant susceptibility. Out of the 164 S. aureus strains tested only 17 strains (10.4\%) had elevated disinfectant susceptibility levels, and they were found among the MLT and PSM strains. Six of the seventeen strains with elevated disinfectant susceptibility levels were determined to be MRSA strains and were determined to have increased S. aureus susceptibility to 18 of $24(75 \%)$ disinfectants tested. There was one MRSA strain among the MLT strains that did not have elevated disinfectant levels. There were two strains among the MLT strains and five strains among the PSM strains that had elevated disinfectant susceptibility but were not MDR. No strains were found with elevated disinfectant susceptibility levels or tested positive for MRSA among the swine feces strains.

When determining which component of $D C \& R^{C P}$ with concentration levels that would inhibit S. aureus, the calculated theo MICs ${ }_{\mathrm{THN}} \mathrm{DC} \& \mathrm{R}$, theo MICs $\mathrm{s}_{\mathrm{BACs}} \mathrm{DC} \& \mathrm{R}$, and theo MICs ${ }_{\text {Form }}{ }^{\text {DC\&R }}$ were compared with the authentic S. aureus MICs against the BACs, $\mathrm{THN}$, and formaldehyde. In general, the calculated theo $\mathrm{MICs}_{\mathrm{BACs}} \mathrm{DC} \& \mathrm{R}$ were at the appropriate levels to inhibit the $S$. aureus strains, and the theo MICs ${ }_{F o r m} D C \& R$ and theo ${ }^{M I C S_{T H N}}{ }^{D C \& R}$ concentrations were too low to inhibit these bacteria. The theo MICs BACs $^{\text {DC\&R, and specifically the levels of theo MICs }}{ }_{C 14 B A C}$ DC\&R and theo MICs ${ }_{C 16 B A C}{ }^{\mathrm{DC} \& \mathrm{R}}$ were sufficient to inhibit the S. aureus strains. Whereas the levels of theo MICs ${ }_{C 12 B A C}{ }^{D C \& R}$ were not sufficient to inhibit 17 of 101 strains $(16.8 \%)$. In previous studies the level of theo ${ }^{\mathrm{MIC}} \mathrm{s}_{\mathrm{BACs}}{ }^{\mathrm{DC} \& \mathrm{R}}$ in $\mathrm{DC} \& \mathrm{R}^{\mathrm{CP}}$ were sufficient to inhibit all pathogenic bacteria previously studied [92-97], except $C$. jejuni [70]. In like manner, when determining which component of $\mathrm{P}-128^{\mathrm{CP}}$ was the active component against S. aureus the calculated ${ }^{\text {theo }} \mathrm{MICs}_{\mathrm{BACs}}{ }^{\mathrm{P}-128}$ and ${ }^{\text {theo }} \mathrm{MICs}_{\mathrm{C} 10 \mathrm{AC}}{ }^{\mathrm{P}-128}$ were compared to 
the authentic $S$. aureus MICs for the BACs and C10AC. The calculated levels for the ${ }^{\text {theo }} \mathrm{MICs}_{\mathrm{BACs}}{ }^{\mathrm{P}-128}$ were not high enough for inhibition of the $S$. aureus strains but the levels of the calculated theo ${ }^{\mathrm{MIC}} \mathrm{S}_{\mathrm{C} 10 \mathrm{AC}}{ }^{\mathrm{P}-128}$ were similar to the levels required for S. aureus inhibition. This result was observed for $\mathrm{P}-128^{\mathrm{CP}}$ against E. coli O157:H7 [92], Ps. aeruginosa [93], non-O157 STEC [94], Salmonella [95], and VRE [97] strains. However, the BACs component of $\mathrm{P}-128^{\mathrm{CP}}$ was the most active against $\mathrm{C}$. coli [96], and the BACs component and C10AC appeared to act equally and synergistically against C. jejuni [70].

The potency of the five-ammonium chloride disinfectant components, C8AC, C10AC, C12BAC, C14BAC, and C16BAC was tested against the $S$. aureus strains and determined that $\mathrm{C} 10 \mathrm{AC}$ and $\mathrm{C} 16 \mathrm{BAC}$ were equally the most effective against S. aureus. C14AC, C12BAC, and $\mathrm{C} 8 \mathrm{AC}$, respectively, required progressively higher concentrations to inhibit the S. aureus strains. However, some of the MLT and PSM strains required higher levels of components C8AC and C12BAC for inhibition of $S$. aureus than the swine feces strains did. The length of the carbon chain attached to the ammonium chloride for each disinfectant component is incorporated into the abbreviated names of the components, C8, C10, C12, C14, and C16. In previous potency studies C10AC, C12BAC, and C14BAC were clearly the most effective against $C$. jejuni [70] and C. coli [96], while C16BAC was the least effective against these two bacteria. Potency studies of disinfectant components against E. coli O157:H7 [92], Ps. aeruginosa [93], non-O157 STECs [94], Salmonella [95], and VRE [97] determined that C10AC was the most effective ammonium chloride disinfectant component against these bacteria.

\section{Conclusions}

A high prevalence of AMR was demonstrated by the 164 S. aureus strains to four antimicrobials, erythromycin (50.6\%), tylosin tartrate $(42.7 \%)$, penicillin $(72 \%)$, and tetracycline $(68.9 \%)$, and no AMR was detected to daptomycin, nitrofurantoin, linezolid, and tigecycline. The MLT and PSM strains demonstrated a wide array of resistance profiles. MRSA strains were found only in the MDR strains from the MLT (25.0\%) and PSM (20.0\%), but not among the swine feces strains. Multilocus sequence typing determined six of the seven MRSA strains isolated from the MLT and PSM were strain ST398 while one strain was ST5. About $17.5 \%$ of the swine feces strains and $41.6 \%$ of the combined MLT and PSM strains were resistant to chlorhexidine. All 164 strains were susceptible to the pseudoantibiotic triclosan and to BKC. The MLT and PSM strains had elevated susceptibilities for the disinfectants, DC\&R ${ }^{C P}$, Tek-Trol ${ }^{C P}$, CaviCide $^{\mathrm{CP}}, \mathrm{P}-128^{\mathrm{CP}}, \mathrm{BKC}, \mathrm{FSS}, \mathrm{F} 25, \mathrm{FS} 512$, OdoBan $^{\mathrm{CP}}$, CPB, CPC, CDEAB, CTAB, C8AC, C10AC, C12BAC, C14BAC, and C16BAC compared to the swine feces strains. Six of the seven MRSA strains demonstrated increased MICs to 18 of 24 (75\%) disinfectants evaluated compared to non-MRSA strains, and they correlated well with increased disinfectant susceptibility. No strains were found with elevated disinfectant susceptibility levels among the swine feces strains. It was determined that the BAC components of DC\& $\mathrm{R}^{\mathrm{CP}}$ were responsible for the inhibition of $S$. aureus strains. The C10AC component in $\mathrm{P}-128^{\mathrm{CP}}$ was responsible for $S$. aureus inhibition. The C10AC and C16BAC were equally effective against $S$. aureus. Some of the MLT and PSM S. aureus strains required higher levels of the components C8AC and C12BAC for inhibition compared to the swine feces strains. Since the $S$. aureus and MRSA strains were found deep within the MLT, this tissue may be a candidate for specialized treatments or even removal from the human consumption market. The use of formaldehyde and THN in the complex disinfectant DC\&R $\mathrm{R}^{\mathrm{CP}}$ is questionable since they are not effective against $S$. aureus at the concentrations present in $\mathrm{DC} \& \mathrm{R}^{\mathrm{CP}}$, and the inclusion of formaldehyde and THN may result in additional unnecessary chemicals in the environment. This study establishes susceptibility values for $S$. aureus strains from swine feces, mandibular lymph node tissue, and commercial pork sausage against 24 disinfectants. Since it was demonstrated that S. aureus and MRSA strains can be found deep within swine lymph node tissue, it may be beneficial for the consumer if raw swine lymph node tissue was not used in food products and pork sausage. 
Supplementary Materials: The following are available online at https: / www.mdpi.com/article / 10.3390/microorganisms9112401/s1, Table S1: Antimicrobial resistance profiles among 63 Staphylococcus aureus strains isolated from swine feces, Table S2: Antimicrobial resistance profiles among 49 Staphylococcus aureus strains isolated from swine mandibular lymph node tissue, Table S3: Antimicrobial resistance profiles among 52 Staphylococcus aureus strains isolated from commercial pork sausage meat, Table S4: Distribution of disinfectant and disinfectant components susceptibility profiles for the 7 MRSA strains isolated from swine mandibular lymph node tissue and pork sausage meat, Table S5: Distribution of disinfectant and disinfectant component susceptibility profiles for 49 Staphylococcus aureus strains isolated from swine mandibular lymph node tissue, Table S6: Distribution of disinfectant and disinfectant component susceptibility profiles for 52 Staphylococcus aureus strains isolated from commercial pork sausage meat.

Author Contributions: Conceptualization, R.C.B.; Investigation, R.C.B., K.A., R.B.H., M.E.H., M.U.S., T.L.P.; Methodology, R.C.B. and K.A.; Supervision, R.C.A.; Writing-original draft, R.C.B.; Writing-review and editing, R.C.B., K.A., R.B.H., M.E.H., M.U.S., T.L.P., T.L.C. and R.C.A. All authors have read and agreed to the published version of the manuscript.

Funding: The work was supported by USDA, ARS normal operating funds.

Institutional Review Board Statement: Not applicable.

Informed Consent Statement: Not applicable.

Data Availability Statement: All data are presented within the text and in the Supplementary Material.

Acknowledgments: We thank Taryn Scholz for reviewing this and many other manuscripts. This work was funded by the USDA, Agricultural Research Service. Mention of trade names, proprietary products or specific equipment is solely for the purpose of providing specific information and does not constitute a guarantee, warranty or endorsement by the U.S. Department of Agriculture does not imply its approval to the exclusion of other products that may be suitable. Additionally, the views expressed in this article are those of the authors and do not necessarily reflect the official policy of the U.S. Department of Agriculture, or the U.S. Government.

Conflicts of Interest: The authors declare no conflict of interest.

\section{References}

1. Diekema, D.J.; Pfaller, M.A.; Schmitz, F.J.; Smayevsky, J.; Bell, J.; Jones, R.N.; Beach, M.; SENTRY Participants Group. Survey of infections due to Staphylococcus species: Frequency of occurrence and antimicrobial susceptibility of isolates collected in the United States, Canada, Latin America, Europe, and the Western Pacific region for the SENTRY Antimicrobial Surveillance Program, 1997-1999. Clin. Infect. Dis. 2001, 32 (Suppl. 2), S114-S132. [CrossRef]

2. Morgan, M. Methicillin-resistant Staphylococcus aureus and animals: Zoonosis or humanosis? J. Antimicrob. Chemother. 2008, 62, 1181-1187. [CrossRef]

3. Cuny, C.; Friedrich, A.; Kozytska, S.; Layer, F.; Nübel, U.; Ohlsen, K.; Strommenger, B.; Walther, B.; Wieler, L.; Witte, W. Emergence of methicillin-resistant Staphylococcus aureus (MRSA) in different animal species. Int. J. Med. Microbiol. 2010, 300, 109-117. [CrossRef] [PubMed]

4. Lassok, B.; Tenhagen, B.-A. From pig to pork: Methicillin-resistant Staphylococcus aureus in the pork production chain. J. Food Protect. 2013, 76, 1095-1108. [CrossRef] [PubMed]

5. Spahich, N.A.; Vitko, N.P.; Thurlow, L.R.; Temple, B.; Richardson, A.R. Staphylococcus aureus lactate-and malate-quinone oxidoreductases contribute to nitric oxide resistance and virulence. Mol. Microbiol. 2016, 100, 759-773. [CrossRef] [PubMed]

6. Saïd-Salim, B.; Dunman, P.M.; McAleese, F.M.; Macapagal, D.; Murphy, E.; McNamara, P.J.; Arvidson, S.; Foster, T.J.; Projan, S.J.; Kreiswirth, B.N. Global regulation of Staphylococcus aureus genes by Rot. J. Bacteriol. 2003, 185, 610-619. [CrossRef]

7. Otero, M.C.; Morelli, L.; Nader-Macías, M.E. Probiotic properties of vaginal lactic acid bacteria to prevent metritis in cattle. Lett. Appl. Microbiol. 2006, 43, 91-97. [CrossRef]

8. Kluytmans, J.; van Belkum, A.; Verbrugh, H. Nasal carriage of Staphylococcus aureus: Epidemiology, underlying mechanisms, and associated risks. Clin. Microbiol. Rev. 1997, 10, 505-520. [CrossRef] [PubMed]

9. Lowy, F.D. Staphylococcus aureus infections. N. Engl. J. Med. 1998, 339, 520-532. [CrossRef]

10. Noskin, G.A.; Rubin, R.J.; Schentag, J.J.; Kluytmans, J.; Hedblom, E.C.; Smulders, M.; Lapetina, E.; Gemmen, E. The burden of Staphylococcus aureus infections on hospitals in the United States: An analysis of the 2000 and 2001 Nationwide Inpatient Sample Database. Arch. Intern. Med. 2005, 165, 1756-1761. [CrossRef]

11. McCaig, L.F.; McDonald, L.C.; Mandal, S.; Jernigan, B. Staphylococcus aureus-associated skin and soft tissue infections in ambulatory care. Emerg. Infect. Dis. 2006, 12, 1715-1723. [CrossRef] 
12. Gould, I.M. Antibiotics, skin and soft tissue infection and methicillin-resistant Staphylococcus aureus: Cause and effect. Int. J. Antimicrob. Agents 2009, 34 (Suppl. 1), S8-S11. [CrossRef]

13. David, M.Z;; Daum, R.S. Community-associated methicillin-resistant Staphylococcus aureus: Epidemiology and clinical consequences of an emerging epidemic. Clin. Microbiol. Rev. 2010, 23, 616-687. [CrossRef]

14. Mohanty, A.; Mohapaira, K.C.; Pal, B.B. Isolation and identification of Staphylococcus aureus from skin and soft tissue infection in sepsis cases, Odisha. J. Pure Appl. Microbiol. 2018, 12, 419-424. [CrossRef]

15. Centers for Disease Control and Prevention. Foodborne Germs and Illnesses. 2019. Available online: https://www.cdc.gov/ foodsafety / foodborne-germs.html (accessed on 26 December 2020).

16. Jevons, M. “Celberin”-resistant staphylococci. Br. Med. J. 1961, 1, 124-125. [CrossRef]

17. Peacock, S.J.; Paterson, G.K. Mechanisms of methicillin resistance in Staphylococcus aureus. Annu. Rev. Biochem. 2015, 84, 577-601. [CrossRef] [PubMed]

18. Lee, A.S.; de Lencastre, H.; Garau, J.; Kluytmans, J.; Malhotra-Kumar, S.; Peschel, A.; Harbarth, S. Methicillin-resistant Staphylococcus aureus. Nat. Rev. Dis. Primers 2018, 31, 18033. [CrossRef] [PubMed]

19. National Center for Case Methicillin resistant Staphylococcus aureus (MRSA). 2020. Available online: https://sciencecases.lib. buffalo.edu/files/Supplemental/UploadFolder/skin_graft.pdf (accessed on 26 December 2020).

20. Hryniewicz, M.M.; Garbacz, K. Borderline oxacillin-resistant Staphylococcus aureus (BORSA)-a more common problem than expected? J. Med. Microbiol. 2017, 66, 1367-1373. [CrossRef] [PubMed]

21. Hassoun, A.; Linden, P.K.; Friedman, B. Incidence, prevalence, and management of MRSA bacteremia across patient populationsA review of recent developments in MRSA management and treatment. Crit. Care 2017, 21, 211. [CrossRef]

22. Kluytmans, J.; van Leeuwen, W.; Goessens, W.; Hollis, R.; Messer, S.; Herwaldt, L.; Bruining, H.; Heck, M.; Rost, J.; van Leeuwen, N.; et al. Food-initiated outbreak of methicillin-resistant Staphylococcus aureus analyzed by pheno-and genotyping. J. Clin. Microbiol. 1995, 33, 1121-1128. [CrossRef]

23. Jones, T.F.; Kellum, M.E.; Porter, S.S.; Bell, M.; Schaffner, W. An outbreak of community-acquired foodborne illness caused by methicillin-resistant Staphylococcus aureus. Emerg. Infect. Dis. 2002, 8, 82-84. [CrossRef]

24. Centers for Disease Control and Prevention. Staphylococcal (Staph) Food Poisoning. 2018. Available online: https:/ /www.cdc. gov/foodsafety/diseases/staphylococcal.html (accessed on 26 December 2020).

25. do Carmo, L.S.; Dias, R.S.; Linardi, V.R.; de Sena, M.J.; dos Santos, D.A.; de Faria, M.E.; Pena, E.C.; Jett, M.; Heneine, L.G. Food poisoning due to enterotoxigenic strains of Staphylococcus present in Minas cheese and raw milk in Brazil. Food Microbiol. 2002, 19, 9-14. [CrossRef]

26. Normanno, G.; Firinu, A.; Virgilio, S.; Mula, G.; Dambrosio, A.; Poggiu, A.; Decastelli, L.; Mioni, R.; Scuota, S.; Bolzoni, G.; et al. Coagulase-positive Staphylococci and Staphylococcus aureus in food products marked in Italy. Int. J. Food Microbiol. 2005, $98,73-79$. [CrossRef] [PubMed]

27. Kérouanton, A.; Hennekinne, J.A.; Letertre, C.; Petit, L.; Chesneau, O.; Brisabois, A.; De Buyer, M.L. Characterization of Staphylococcus aureus strains associated with food poisoning outbreaks in France. Int. J. Food Microbiol. 2007, 115, 369-375. [CrossRef] [PubMed]

28. Tsegmed, U.; Normanno, G.; Pringle, M.; Krovacek, K. Occurrence of enterotoxic Staphylococcus aureus in raw milk from yaks and cattle in Mongolia. J. Food Protect. 2007, 70, 1726-1729. [CrossRef] [PubMed]

29. Medved'ová, A.; Valík, L'.; Sirotná, Z.; Liptáková, D. Growth characterisation of Staphylococcus aureus in milk: A quantitative approach. Czech. J. Food Sci. 2009, 27, 443-453. [CrossRef]

30. Medved'ová, A.; Valík, L'. Staphylococcus aureus: Characterisation and quantitative growth description in milk and artisanal raw milk cheese production. In Structure and Function of Food Engineering; Eissa, A.A., Ed.; IntechOpen: London, UK, 2012. Available online: https://www.intechopen.com/books/structure-and-function-of-food-engineering/staphylococcus-aureuscharacterisation-and-quantitative-growth-description-in-milk-and-artisanal-raw (accessed on 4 February 2021). [CrossRef]

31. Halpin-Dohnalek, M.I.; Marth, E.H. Staphylococcus aureus: Production of extracellular compounds and behavior in foods-A review. J. Food Protect. 1989, 52, 267-282. [CrossRef]

32. Baird-Parker, T.C. Staphylococcus aureus. Chapter 47. In The Microbiological Safety and Quality of Food; Lund, B.M., Baird-Parker, T.C., Gould, G.W., Gaithersburg, M.D., Eds.; Aspen Publishers Inc.: New York, NY, USA, 2000; pp. 1317-1330, ISBN 0-8342-1323-0.

33. Ananou, S.; Maqueda, M.; Martínez-Bueno, M.; Gálvez, A.; Valdivia, E. Control of Staphylococcus aureus in sausages by enterocin AS-48. Meat Sci. 2005, 71, 549-556. [CrossRef]

34. Azimirad, M.; Dezfulian, A.; Alebouyeh, M.; Esfehani, R.B.; Shahroskh, S.; Zali, M.R. Infection with enterotoxigenic Staphylococcus aureus as a concern in patients with gastroenteritis. J. Glob. Antimicrob. Res. 2017, 9, 111-114. [CrossRef]

35. Pexara, A.; Bourriel, A.; Govaris, A. Staphylococcus aureus and Staphylococcal enterotoxins in foodborne diseases. J. Hell. Vet. Med. Soc. 2018, 61, 316-322. [CrossRef]

36. Seo, K.S.; Bohach, G.A. Staphylococcus aureus, Chapter 21. In Food Microbiology: Fundamentals and Frontiers, 4th ed.; Doyle, M.P., Buchanan, R.L., Eds.; ASM Press: Washington, DC, USA, 2012; pp. 547-573. [CrossRef]

37. Craven, S.E.; Blankenship, L.C.; Mercuri, A.J. Growth and production of enterotoxin by Staphylococcus aureus S-6 in soy proteins and soy-supplemented beef and pork sausage. J. Food Protect. 1978, 41, 794-797. [CrossRef] 
38. Verstappen, K.M.; Willems, E.; Fluit, A.C.; Duim, B.; Martens, M.; Wagenaar, J.A. Staphylococcus aureus nasal colonization differs among pig lineages and is associated with the presence of other staphylococcal species. Front. Vet. Sci. 2017, 4, 97. [CrossRef] [PubMed]

39. Weese, J.S. Methicillin-resistant Staphylococcus aureus in animals. ILAR J. 2010, 51, 233-244. [CrossRef] [PubMed]

40. Carrel, M.; Schweizer, M.L.; Sarrazin, M.V.; Smith, T.C.; Perencevich, E.N. Residential proximity to large numbers of swine in feeding operations is associated with increased risk of methicillin-resistant Staphylococcus aureus colonization at time of hospital admission in rural Iowa veterans. Infect. Control Hosp. Epidemiol. 2014, 35, 190-192. [CrossRef] [PubMed]

41. Hau, S.J.; Sun, J.; Davies, P.R.; Frana, T.S.; Nicholson, T.L. Comparative prevalence of immune evasion complex genes associated with $\beta$-hemolysin converting bacteriophages in MRSA ST5 isolates from swine, swine facilities, humans with swine contact, and humans with no swine contact. PLoS ONE 2015, 10, e0142832. [CrossRef]

42. Kadlec, K.; Feßler, A.T.; Hauscheld, T.; Schwarz, S. Novel and uncommon antimicrobial resistance genes in livestock-associated methicillin-resistant Staphylococcus aureus. Clin. Microbiol. Infect. 2012, 18, 745-755. [CrossRef]

43. Akwar, T.H.; Poppe, C.; Wilson, J.; Reid-Smith, R.J.; Dyck, M.; Waddington, J.; Shang, N.; Dassie, S.A.; McEwen, S.A. Risk factors for antimicrobial resistance among fecal Escherichia coli from residents on forty-three swine farms. Microb. Drug Resist. 2007, 13, 69-76. [CrossRef]

44. Silbergeld, E.K.; Graham, J.; Price, L.B. Industrial food animal production, antimicrobial resistance, and human health. Ann. Rev. Pub. Health 2008, 29, 51-169. [CrossRef]

45. Voss, A.; Loeffen, F.; Bakker, J.; Klaassen, C.; Wulf, M. Methicillin-resistant Staphylococcus aureus in pig farming. Emerg. Infect. Dis. 2005, 11, 1965-1966. [CrossRef]

46. de Neeling, A.J.; van den Broek, M.J.M.; Spalburg, E.C.; van Santen-Verheuvel, M.G.; Dam-Deisz, W.D.C.; Boshuizen, H.C.; van de Giessen, A.W.; van Duijkeren, E.; Huijsdens, X.W. High prevalence of methicillin resistant Staphylococcus aureus in pigs. Vet. Microbiol. 2007, 122, 366-372. [CrossRef]

47. Lewis, H.C.; Mølbak, K.; Reese, C.; Aarestrup, F.M.; Selchau, M.; Sørum, M.; Skov, R.L. Pigs as source of methicillin-resistant Staphylococcus aureus CC398 infections in humans, Denmark. Emerg. Infect. Dis. 2008, 14, 1383-1389. [CrossRef] [PubMed]

48. Smith, T.C.; Male, M.J.; Harper, A.L.; Kroeger, J.S.; Tinkler, G.P.; Moritz, E.D.; Capuano, A.W.; Herwaldt, L.A.; Diekema, D.J. Methicillin-resistant Staphylococcus aureus (MRSA) strain ST398 is present in midwestern U.S. swine and swine workers. PLoS ONE 2009, 4, e4258. [CrossRef] [PubMed]

49. Rinsky, J.L.; Nadimpalli, M.; Wing, S.; Hall, D.; Baron, D.; Price, L.B.; Larsen, J.; Stegger, M.; Stewart, J.; Heaney, C.A. Livestockassociated methicillin and multidrug resistant Staphylococcus aureus is present among industrial, not antibiotic-free livestock operation workers in North Carolina. PLoS ONE 2013, 8, e67641. [CrossRef]

50. Nadimpalli, M.; Rinsky, J.L.; Wing, S.; Hall, D.; Stewart, J.; Larsen, J.; Nachman, K.E.; Love, D.C.; Pierce, E.; Pisanic, N.; et al. Persistence of livestock-associated antibiotic-resistant Staphylococcus aureus among industrial hog operation workers in North Carolina over 14 days. Occup. Environ. Med. 2015, 72, 90-99. [CrossRef]

51. Köck, R.; Harlizius, J.; Bressan, N.; Laerberg, R.; Wieler, L.H.; Witte, W.; Deurenberg, R.H.; Voss, A.; Becker, K.; Friedrich, A.W. Prevalence and molecular characteristics of methicillin-resistant Staphylococcus aureus (MRSA) among pigs on German farms and import of livestock-related MRSA into hospitals. Eur. J. Clin. Microbiol. Infect. Dis. 2009, 28, 1375-1382. [CrossRef]

52. Köck, R.; Siam, K.; Al-Malat, S.; Christmann, J.; Schaumburg, F.; Becker, K.; Friedrich, A.W. Characteristics of hospital patients colonized with livestock-associated methicillin-resistant Staphylococcus aureus (MRSA) CC398 versus other MRSA clones. J. Hosp. Infect. 2011, 79, 292-296. [CrossRef]

53. Wulf, M.W.H.; Verduin, C.M.; van Nes, A.; Huijsdens, X.; Voss, A. Infection and colonization with methicillin resistant Staphylococcus aureus ST398 versus other MRSA in an area with a high density of pig farms. Eur. J. Clin. Microbiol. Infect. Dis. 2012, 31, 61-65. [CrossRef]

54. Smith, T.C.; Gebreyes, W.A.; Abley, M.J.; Harper, A.L.; Forshey, B.M.; Male, M.J.; Martin, H.W.; Molla, B.Z.; Sreevatsan, S.; Thakur, S.; et al. Methicillin-resistant Staphylococcus aureus in pigs and farm workers on conventional and antibiotic-free swine farms in the USA. PLoS ONE 2013, 8, e63704. [CrossRef]

55. O’Brien, A.M.; Hanson, B.M.; Farina, S.A.; Wu, J.Y.; Simmering, J.E.; Wardyn, S.E.; Forshey, B.M.; Kulick, M.E.; Wallinga, D.B.; Smith, T.C. MRSA in conventional and alternative retail pork products. PLoS ONE 2012, 7, e30092. [CrossRef]

56. Verkade, E.; Kluytmans, J. Livestock-associated Staphylococcus aureus CC398: Animal reservoirs and human infections. Infect. Genet. Evol. 2014, 21, 523-530. [CrossRef]

57. Anjum, M.F.; Marco-Jimenez, F.; Duncan, D.; Marín, C.; Smith, R.P.; Evans, S.J. Livestock-associated methicillin-resistant Staphylococcus aureus from animals and animal products in the UK. Front. Microbiol. 2019, 10, 2136. [CrossRef]

58. Parisi, A.; Caruso, M.; Normanno, G.; Latorre, L.; Miccolupo, A.; Fraccalvieri, R.; Intini, F.; Manginelli, T.; Santagada, G. MRSA in swine, farmers and abattoir workers in Southern Italy. Food Microbiol. 2019, 82, 287-293. [CrossRef]

59. Cuny, C.; Wieler, L.H.; Witte, W. Livestock-associated MRSA: The impact on humans. Antibiotics 2015, 4, 521-543. [CrossRef] [PubMed]

60. Smith, T.C.; Wardyn, S.E. Human infections with Staphylococcus aureus CC398. Cur. Environ. Health Rpt. 2015, 2, 41-51. [CrossRef] [PubMed] 
61. Wardyn, S.E.; Forshey, B.M.; Farina, S.A.; Kates, A.E.; Nair, R.; Quick, M.K.; Wu, J.Y.; Hanson, B.M.; O’Malley, S.M.; Shows, H.W.; et al. Swine farming is a risk factor for infection with high prevalence of carriage of multidrug-resistant Staphylococcus aureus. Clin. Infect. Dis. 2015, 61, 59-66. [CrossRef] [PubMed]

62. Nadimpalli, M.; Stewart, J.R.; Pierce, E.; Pisanic, N.; Love, D.C.; Hall, D.; Larsen, J.; Carroll, D.C.; Tekle, T.; Perl, T.M.; et al. Livestock-associated, antibiotic-resistant Staphylococcus aureus nasal carriage and recent skin and soft tissue infection among industrial hog operation workers. PLoS ONE 2016, 11, e0165713. [CrossRef]

63. Ye, X.; Fan, Y.; Wang, X.; Liu, W.; Yu, H.; Zhou, J.; Chen, S.; Yao, Z. Livestock-associated methicillin and multidrug resistant S. aureus in humans is associated with occupational pig contact, and pet contact. Sci. Rep. 2016, 6, 19184. [CrossRef]

64. Hatcher, S.M.; Rhodes, S.M.; Stewart, J.R.; Silbergweld, E.; Pisanic, N.; Larsen, J.; Jiang, S.; Krosche, A.; Hall, D.; Carroll, K.C.; et al. The prevalence of antibiotic-resistant Staphylococcus aureus nasal carriage among industrial hog operation workers, community residents, and children living in their households: North Carolina, USA. Environ. Health Perspect. 2017, 125, 560-569. [CrossRef]

65. Davis, M.F.; Pisanic, N.; Rhodes, S.M.; Brown, A.; Keller, H.; Nadimpalli, M.; Christ, A.; Ludwig, S.; Ordak, C.; Spicer, K.; et al. Occurrence of Staphylococcus aureus in swine and swine workplace environments on industrial and antibiotic-free hog operations in North Carolina, USA: A one health pilot study. Environ. Res. 2018, 163, 88-96. [CrossRef]

66. Centers for Disease Control and Prevention. Four pediatric deaths from community-acquired methicillin-resistant Staphylococcus aureus-Minnesota and North Dakota, 1997-1999. Morb. Mortal. Wkly. Rep. 1999, 48, 707-710. [PubMed]

67. Bens, C.C.; Voss, A.; Klaassen, C.H. Presence of a novel DNA methylation enzyme in methicillin-resistant Staphylococcus aureus isolates associated with pig farming leads to uninterpretable results in standard pulsed-field gel electrophoresis analysis. J. Clin. Microbiol. 2006, 44, 1875-1876. [CrossRef]

68. Enright, M.C.; Day, N.P.J.; Davies, C.E.; Peacock, S.J.; Spratt, B.G. Multilocus sequence typing for characterization of methicillinresistant and methicillin-susceptible clones of Staphylococcus aureus. J. Clin. Microbiol. 2000, 38, 1008-1015. [CrossRef] [PubMed]

69. Beier, R.C.; Bischoff, K.M.; Ziprin, R.L.; Poole, T.L.; Nisbet, D.J. Chlorhexidine susceptibility, virulence factors, and antibiotic resistance of beta-hemolytic Escherichia coli isolated from neonatal swine with diarrhea. Bull. Environ. Contam. Toxicol. 2005, 75, 835-844. [CrossRef] [PubMed]

70. Beier, R.C.; Byrd, J.A.; Andrews, K.; Caldwell, D.; Crippen, T.L.; Anderson, R.C.; Nisbet, D.J. Disinfectant and antimicrobial susceptibility studies of the foodborne pathogen Campylobacter jejuni isolated from the litter of broiler chicken houses. Poult. Sci. 2021, 100, 1024-1033. [CrossRef] [PubMed]

71. White, D.G.; McDermott, P.F. Biocides, drug resistance and microbial evolution. Curr. Opin. Microbiol. 2001, 4, 313-317. [CrossRef]

72. Maris, P. Resistance of 700 gram-negative bacterial strains to antiseptics and antibiotics. Ann. Rech. Vet. 1991, 22, 11-23.

73. Sidhu, M.S.; Heir, E.; Leegaard, T.K.; Wiger, K.; Holck, A. Frequency of disinfectant resistance genes and genetic linkage with $\beta$-lactamase transposon Tn552 among clinical staphylococci. Antimicrob. Agents Chemother. 2002, 46, 2797-2803. [CrossRef]

74. Braoudaki, M.; Hilton, A.C. Adaptive resistance to biocides in Salmonella enterica and Escherichia coli O157 and cross-resistance to antimicrobial agents. J. Clin. Microbiol. 2004, 42, 73-78. [CrossRef]

75. Davin-Regli, A.; Pagès, J.-M. Cross-resistance between biocides and antimicrobials: An emerging question. Rev. Sci. Tech. Int. Off. Epiz. 2012, 31, 89-104. [CrossRef]

76. Al-Jailawi, M.H.; Ameen, R.S.; Al-Jeboori, M.R. Effect of disinfectants on antibiotics susceptibility of Pseudomonas aeruginosa. J. Appl. Biotechnol. 2013, 1, 54-63. [CrossRef]

77. Gnanadhas, D.P.; Marathe, S.A.; Chakravortty, D. Biocides-Resistance, cross-resistance mechanisms and assessment. Expert Opin. Investig. Drugs 2013, 22, 191-206. [CrossRef] [PubMed]

78. Johnson, J.G.; Saye, E.J.; Jimenez-Truque, N.; Soper, N.; Thomsen, I.; Talbot, T.R.; Creech, C.B. Frequency of disinfectant resistance genes in pediatric strains of methicillin-resistant Staphylococcus aureus. Infect. Control Hosp. Epidemiol. 2013, 34, $1326-1327$. [CrossRef] [PubMed]

79. Wales, A.D.; Davies, R.H. Co-selection of resistance to antibiotics, biocides and heavy metals, and its relevance to foodborne pathogens. Antibiotics 2015, 4, 567-604. [CrossRef]

80. Romaro, J.L.; Burgos, M.J.G.; Pérez-Pulido, R.; Gálvez, A.; Lucas, R. Resistance to antibiotics, biocides, preservatives and metals in bacteria isolated from seafoods: Co-selection of strains resistant or tolerant to different classes of compounds. Front. Microbiol. 2017, 8, 1650. [CrossRef] [PubMed]

81. Wand, M.E.; Bock, L.J.; Bonney, L.C.; Sutton, J.M. Mechanisms of increased resistance to chlorhexidine and cross-resistance to colistin following exposure of Klebsiella pneumoniae clinical isolates to chlorhexidine. Antimicrob. Agents Chemother. 2017, 61, 1-31. [CrossRef]

82. Cadena, M.; Kelman, T.; Marco, M.L.; Pitesky, M. Understanding antimicrobial resistance (AMR) profiles of Salmonella biofilm and planktonic bacteria challenged with disinfectants commonly used during poultry processing. Foods 2019, 8, 275. [CrossRef]

83. Morente, E.O.; Fernández-Fuentes, M.A.; Grande Burgos, M.J.; Abriouel, H.; Pulido, R.P.; Gálvez, A. Biocide tolerance in bacteria Int. J. Food Microbiol. 2013, 162, 13-25. [CrossRef]

84. Capita, R.; Riesco-Peláez, F.; Alonso-Hernando, A.; Alonso-Calleja, C. Exposure of Escherichia coli ATCC 12806 to sublethal concentrations of food-grade biocides influences its ability to form biofilm, resistance to antimicrobials, and ultrastructure. Appl. Environ. Microbiol. 2014, 80, 1268-1280. [CrossRef] 
85. Ziech, R.E.; Perin, A.P.; Lampurnani, C.; Sereno, M.J.; Viana, C.; Soares, V.M.; Pereira, J.G.; Pinto, J.P.d.A.N.; Bersot, L.d.S. Biofilm-processing ability and tolerance to industrial sanitizers in Salmonella spp. isolated from Brazilian poultry processing plants. LWT Food Sci. Technol. 2016, 68, 85-90. [CrossRef]

86. Takasaki, A.; Hashida, T.; Fujiwara, S.; Kato, K.-I.; Nishihara, T. Bactericidal action of a quaternary ammonium disinfectant, didecyldimethyl ammonium chloride, against Staphylococcus aureus. Jpn. J. Toxicol. Environ. Health 1994, 40, 344-350. [CrossRef]

87. Ioannou, C.J.; Hanlon, G.W.; Denyer, S.P. Action of disinfectant quaternary ammonium compounds against Staphylococcus aureus. Antimicrob. Agents Chemother. 2007, 51, 296-306. [CrossRef] [PubMed]

88. Heir, E.; Sundheim, G.; Holck, A.L. Resistance to quaternary ammonium compounds in Staphylococcus spp. isolated from the food industry and nucleotide sequence of the resistance plasmid pST827. J. Appl. Bacteriol. 1995, 79, 149-156. [CrossRef] [PubMed]

89. Rutala, W.A.; Barbee, S.L.; Aguiar, N.C.; Sobsey, M.D.; Weber, D.J. Antimicrobial activity of home disinfectants and natural products against potential human pathogens. Infect. Control Hosp. Epidemiol. 2000, 21, 33-38. [CrossRef] [PubMed]

90. Aboualizadeh, E.; Bumah, V.V.; Masson-Meyers, D.S.; Eells, J.T.; Hirschmugl, C.J.; Enwermeka, C.S. Understanding the antimicrobial activity of selected disinfectants against methicillin-resistant Staphylococcus aureus (MRSA). PLoS ONE 2017, 12, e0186375. [CrossRef]

91. Lineback, C.B.; Nkemngong, C.A.; Wu, S.T.; Li, X.; Teska, P.J.; Oliver, H.F. Hydrogen peroxide and sodium hypochlorite disinfectants are more effective against Staphylococcus aureus and Pseudomonas aeruginosa biofilms than quaternary ammonium compounds. Antimicrob. Resist. Infect. Control 2018, 7, 154. [CrossRef] [PubMed]

92. Beier, R.C.; Poole, T.L.; Brichta-Harhay, D.M.; Anderson, R.C.; Bischoff, K.M.; Hernandez, C.A.; Bono, J.L.; Arthur, T.M.; Nagaraja, T.G.; Crippen, T.L.; et al. Disinfectant and antibiotic susceptibility profiles of Escherichia coli O157:H7 strains from cattle carcasses, feces, and hides and ground beef from the United States. J. Food Protect. 2013, 76, 6-17. [CrossRef]

93. Beier, R.C.; Foley, S.L.; Davidson, M.K.; White, D.G.; McDermott, P.F.; Bodeis-Jones, S.; Zhao, S.; Andrews, K.; Crippen, T.L.; Sheffield, C.L.; et al. Characterization of antibiotic and disinfectant susceptibility profiles among Pseudomonas aeruginosa veterinary isolates recovered during 1994-2003. J. Appl. Microbiol. 2014, 118, 326-342. [CrossRef]

94. Beier, R.C.; Franz, E.; Bono, J.L.; Mandrell, R.E.; Fratamico, P.M.; Callaway, T.R.; Andrews, K.; Poole, T.L.; Crippen, T.L.; Sheffield, C.L.; et al. Disinfectant and antimicrobial susceptibility profiles of the big six non-O157 Shiga toxin-producing Escherichia coli strains from food animals and humans. J. Food Protect. 2016, 79, 1355-1370. [CrossRef]

95. Beier, R.C.; Callaway, T.R.; Andrews, K.; Poole, T.L.; Crippen, T.L.; Anderson, R.C.; Nisbet, D.J. Disinfectant and antimicrobial susceptibility profiles of Salmonella strains from feedlot water-sprinkled cattle: Hides and feces. J. Food Chem. Nanotechnol. 2017, 3, 50-59. [CrossRef]

96. Beier, R.C.; Harvey, R.B.; Hernandez, C.A.; Andrews, K.; Droleskey, R.E.; Hume, M.E.; Davidson, M.K.; Bodeis-Jones, S.; Young, S.; Anderson, R.C.; et al. Disinfectant and antimicrobial susceptibility profiles of Campylobacter coli isolated in 1998 to 1999 and 2015 from swine and commercial pork chops. J. Food Sci. 2019, 84, 1501-1512. [CrossRef]

97. Beier, R.C.; Duke, S.E.; Ziprin, R.L.; Harvey, R.B.; Hume, M.E.; Poole, T.L.; Scott, H.M.; Highfield, L.D.; Alali, W.Q.; Andrews, K.; et al. Antibiotic and disinfectant susceptibility profiles of vancomycin-resistant Enterococcus faecium (VRE) isolated from community wastewater in Texas. Bull. Environ. Contam. Toxicol. 2008, 80, 188-194. [CrossRef]

98. Beier, R.C.; Andrews, K.; Poole, T.L.; Harvey, R.B.; Crippen, T.L.; Anderson, R.C.; Nisbet, D.J. Interactions of organic acids with Staphylococcus aureus and MRSA strains from swine mandibular lymph node tissue, commercial pork sausage meat and feces. Int. J. Microbiol. Biotechnol. 2020, 5, 165-183. [CrossRef]

99. Clinical and Laboratory Standards Institute. Performance standards for antimicrobial disk and dilution susceptibility tests for bacteria isolated from animals. In Approved Standard—3rd Edition_Document VET01S; Clinical and Laboratory Standards Institute: Wayne, PA, USA, 2015.

100. Clinical and Laboratory Standards Institute. Methods for dilution antimicrobial susceptibility tests for bacteria that grow aerobically. In Approved Standard-11th Edition-Document M07; Clinical and Laboratory Standards Institute: Wayne, PA, USA, 2018.

101. Langsrud, S.; Sundheim, G. Factors influencing a suspension test method for antimicrobial activity of disinfectants. J. Appl. Microbiol. 1998, 85, 1006-1012. [CrossRef] [PubMed]

102. Andrews, J.M. Determination of minimum inhibitory concentrations. J. Antimicrob. Chemother. 2001, 48 (Suppl. 1), 5-16. [CrossRef]

103. Beier, R.C.; Byrd, J.A.; Caldwell, D.; Andrews, K.; Crippen, T.L.; Anderson, R.C.; Nisbet, D.J. Inhibition and interactions of Camplylobactder jejuni from broiler chicken houses with organic acids. Microorganisms 2019, 7, 223. [CrossRef]

104. Galaxy Australia. Galaxy Training Materials. 2021. Available online: https://usegalaxy.org.au/ (accessed on 26 April 2021).

105. CaviCide ${ }^{\mathrm{TM}}$ : Surface Disinfectants. 2021. Available online: https://www.metrex.com/en-us/products/surface-disinfectants/ cavicide/ (accessed on 15 February 2021).

106. Triclocarban Information. 2021. Available online: https://www.cosmeticsinfo.org/triclocarban-information (accessed on 15 February 2021).

107. Satyro, S.; Saggioro, E.M.; Veríssimo, F.; Buss, D.F.; de Magalhães, D.P.; Oliveira, A. Triclocarban: UV photolysis, wastewater disinfection, and ecotoxicity assessment using molecular biomarkers. Environ. Sci. Pollut. Res. 2017, 24, 16077-16085. [CrossRef]

108. Chen, J.; Ahn, K.C.; Gee, N.A.; Ahmed, M.I.; Duleba, A.J.; Zhao, L.; Gee, S.J.; Hammock, B.D.; Lasley, B.L. Triclocarban enhances testosterone action: A new type of endocrine disruptor? Endocrinology 2008, 149, 1173-1179. [CrossRef] 
109. Tarnow, P.; Tralau, T.; Hunecke, D.; Luch, A. Effects of triclocarban on the transcription of estrogen, androgen and aryl hydrocarbon receptor responsive genes in hman breast cancer cells. Toxicol. Vitr. 2013, 27, 1467-1475. [CrossRef] [PubMed]

110. Heath, R.J.; Rock, C.O. A triclosan-resistant bacterial enzyme. Nature 2000, 406, 145-146. [CrossRef]

111. Leelaporn, A.; Paulsen, I.T.; Tennent, J.M.; Littlejohn, T.G.; Skurray, R.A. Multidrug resistance to antiseptics and disinfectants in coagulase-negative staphylococci. J. Med. Microbiol. 1994, 40, 214-220. [CrossRef]

112. Sidhu, M.S.; Sørum, H.; Holck, A. Resistance to quaternary ammonium compounds in food-related bacteria. Microb. Drug Resist. 2002, 8, 393-399. [CrossRef]

113. Tdenover, F.C. Mechanisms of antimicrobial resistance in bacteria. Am. J. Infect. Control 2006, 34 (5 Suppl. 1), S3-S10. [CrossRef]

114. Piatkowska, E.; Piatkowski, J.; Przondo-Mordarska, A. The strongest resistance of Staphylococcus aureus to erythromycin is caused by decreasing uptake of the antibiotic into the cells. Cell. Molecul. Biol. Lett. 2012, 17, 633-645. [CrossRef]

115. Feßler, A.T.; Li, J.; Kadlec, K.; Wang, Y.; Schwarz, S. Antimicrobial resistance properties of Staphylococcus aureus, Chapter 4. In Staphylococcus aureus; Fetsch, A., Cambridge, M.A., Eds.; Academic Press: Cambridge, MA, USA, 2018; pp. 57-85. [CrossRef]

116. Graveland, H.; Wagenaar, J.A.; Heesterbeek, H.; Mevius, D.; van Duijkeren, E.; Heederik, D. Methicillin resistant Staphylococcus aureus ST398 in veal calf farming: Human MRSA carriage related with animal antimicrobial usage and farm hygiene. PLoS ONE 2010, 5, e10990. [CrossRef] [PubMed]

117. European Food Safety Authority. Analysis of the baseline survey on the prevalence of methicillin-resistant Staphylococcus aureus (MRSA) in holdings with breeding pigs, in the EU, 2008. Part A: MRSA prevalence estimates. EFSA J. 2009, 7, 1376. [CrossRef]

118. Wagenaar, J.A.; Yue, H.; Pritchard, J.; Broekhuizen-Stins, M.; Huijsdens, X.; Mevius, D.J.; Bosch, T.; Van Duijkeren, E. Unexpected sequence types in livestock associated methicillin-resistant Staphylococcus aureus (MRSA): MRSA ST9 and a single locus variant of ST9 in pig farming in China. Vet. Microbiol. 2009, 139, 405-409. [CrossRef] [PubMed]

119. Hasman, H.; Moodley, A.; Guardabassi, L.; Stegger, M.; Skov, R.L.; Aarestrup, F.M. spa type distribution in Staphylococcus aureus originating from pigs, cattle and poultry. Vet. Microbiol. 2010, 141, 326-331. [CrossRef]

120. Khanna, T.; Friendship, R.; Dewey, C.; Weese, J.S. Methicillin resistant Staphylococcus aureus colonization in pigs and pig farmers. Vet. Microbiol. 2008, 128, 298-303. [CrossRef]

121. Witte, W.; Strommenger, B.; Stanek, C.; Cuny, C. Methicillin-resistant Staphylococcus aureus ST398 in humans and animals, Central Europe. Emerg. Infect. Dis. 2007, 13, 255-258. [CrossRef]

122. Krziwanek, K.; Metz-Gercek, S.; Mittermayer, H. Methicillin-resistant Staphylococcus aureus ST398 from human patients, upper Austria. Emerg. Infect. Dis. 2009, 15, 766-769. [CrossRef]

123. Golding, G.R.; Bryden, L.; Levett, P.N.; McDonald, R.R.; Wong, A.; Wylie, J.; Graham, M.R.; Tyler, S.; Van Domselaar, G.; Simor, A.E.; et al. Livestock-associated methicillin-resistant Staphylococcus aureus sequence type 398 in humans, Canada. Emerg. Infect. Dis. 2010, 16, 587-594. [CrossRef] [PubMed]

124. Bhat, M.; Dumortier, C.; Taylor, B.S.; Miller, M.; Vasquez, G.; Yunen, J.; Brudney, K.; Sánchez-E, J.; Rodriguez-Taveras, C.; Rojas, R.; et al. Staphylococcus aureus ST398, New York City and Dominican Republic. Emerg. Infect. Dis. 2009, 15, $285-287$. [CrossRef] [PubMed]

125. Beneke, B.; Klees, S.; Stührenberg, B.; Fetsch, A.; Kraushaar, B.; Tenhagen, B.-A. Prevalence of methicillin-resistant Staphylococcus aureus in a fresh meat pork production chain. J. Food Protect. 2011, 74, 126-129. [CrossRef] [PubMed]

126. Ekkclcnkamp, M.B.; Sckkar, M.; Carpaij, N.; Troelstra, A.; Bonten, M.J.M. Endocarditis due to methicillin-resistant Staphylococcus aureus originating from pigs. Ned. Tijdschn. Geneeskd. 2006, 150, 2442-2447.

127. Hartmeyer, G.N.; Gahrn-Hansen, B.; Skov, R.L.; Kolmos, H.J. Pig-associated methicillin-resistant Staphylococcus aureus: Family transmission and severe pneumonia in a newborn. Scand. J. Infect. Dis. 2010, 42, 318-320. [CrossRef] [PubMed]

128. Mammina, C.; Bonura, C.; di Carlo, P.; Calà, C.; Aleo, A.; Monastero, R.; Palma, D.M. Daptomycin non-susceptible, vancomycin intermediate methicillin-resistant Staphylococcus aureus ST398 from a chronic leg ulcer, Italy. Scand. J. Infect. Dis. 2010, 42, 955-957. [CrossRef]

129. Valentin-Domelier, A.-S.; Girard, M.; Bertrand, X.; Violette, J.; François, P.; Donnio, P.-Y.; Talon, D.; Quentin, R.; Schrenzel, J.; van der Mee-Marquet, N.; et al. Methicillin-susceptible ST398 Staphylococcus aureus responsible for bloodstream infections: An emerging human-adapted subclone? PLoS ONE 2011, 6, e28369. [CrossRef]

130. Coombs, G.W.; Pang, S.; Daley, D.A.; Lee, Y.T.; Abraham, S.; Leroi, M. Severe disease caused by community-associated MRSA ST398 Type V, Australia, 2017. Emerg. Infect. Dis. 2019, 25, 190-192. [CrossRef]

131. Park, J.Y.; Jin, J.S.; Kang, H.Y.; Jeong, E.H.; Lee, J.C.; Lee, Y.C.; Seol, S.Y.; Cho, D.T.; Kim, J. A comparison of adult and pediatric methicillin-resistant Staphylococcus aureus isolates collected from patients at a university hospital in Korea. J. Microbiol. 2007, 45, $447-452$.

132. Beier, R.C.; Anderson, P.N.; Hume, M.E.; Poole, T.L.; Duke, S.E.; Crippen, T.L.; Sheffield, C.L.; Caldwell, D.J.; Byrd, J.A.; Anderson, R.C. Characterization of Salmonella enterica isolates from turkeys in commercial processing plants for resistance to antibiotics, disinfectdants, and a growth promoter. Foodborne Pathog. Dis. 2011, 8, 593-600. [CrossRef]

133. Webber, M.A.; Buckner, M.M.C.; Redgrave, L.S.; Ifill, G.; Mitchenall, L.A.; Webb, C.; Iddles, R.; Maxwell, A.; Maxwell, A.; Piddock, L.J.V. Quinolone-resistant gyrase mutants demonstrate decreased susceptibility to triclosan. J. Antimicrob. Chemother. 2017, 72, 2755-2763. [CrossRef] [PubMed]

134. Lu, J.; Jin, M.; Nguyen, S.H.; Mao, L.; Li, J.; Coin, L.J.M.; Yuan, Z.; Guo, J. Non-antibiotic antimicrobial triclosan induces multiple antibiotic resistance through genetic mutation. Environ. Int. 2018, 118, 257-265. [CrossRef] [PubMed] 
135. Pacific Texchem Private Limited. Benzalkonium Chloride-Benzalkonium Chloride 80 Manufacturer from Mumbai. 2021. Available online: pacifictexchem.com (accessed on 16 March 2021).

136. Sharkey, J.W. Benzalkonium Chloride (BZK) Hand Sanitizers During Covid-19. 2020. Available online: linkedin.com (accessed on 16 March 2021). 